\title{
Will Culling the Northwest Atlantic Gray Seal Population, Halichoerus grypus (Fabricius, 1791) (Carnivora: Phocidae) on Cape Cod, Massachusetts, USA Reduce the Risk of Human-White Shark Encounters? ${ }^{1}$
}

\author{
Kimberley Crocker Pearson ${ }^{2}$
}

\begin{abstract}
A recent fatality from a white shark bite in Massachusetts, U.S.A. has led local officials and members of the public to consider culling the population of gray seals in local waters. The seal population, which has been visibly increasing coincident with implementation of the Marine Mammal Protection Act, is thought to have attracted the white shark predators to the area. Were stakeholders to seek scientific evidence to inform a decision to cull, they would find little guidance. This study examines the scientific literature on culling and its impacts both on the species of concern and their ecosystems. Possible culling impacts are considered in the context of the biology and ecology of the Cape gray seal and white shark populations. Results are presented to inform decisionmakers about the feasibility, likely outcome and potential complications of a gray seal cull. The conclusion reached is that culling the Cape Cod gray seals is unlikely to abate the risk of human-white shark encounters on the Cape Cod beaches and could possibly have unforeseen consequences both for the local ecosystem and human activity.
\end{abstract}

Key Words: Culling, Northwest Atlantic Gray Seal, Halichoerus grypus, Carnivora, Phocidae, Cape Cod, Massachusetts, USA, White Shark, Carcharodon carcharias, humans, marine mammal policy

\section{Introduction}

Human-wildlife conflicts occur when wildlife populations are perceived to compete with or threaten human activities in a given area (Madden 2008). Activities like farming, fishing, recreation and even simply occupying living space can shrink the population of and potential habitat available to wildlife species. Competition or threat is most likely to be perceived by a human community when the alleged perpetrator is a larger and more visible species; one of the so-called "charismatic megafauna" (Albert et al. 2018). Upon observing detrimental behaviors by these animals, local communities may seek to reduce or eliminate them. This can take two forms: harvesting, in which animals are removed to utilize them in some way, such as for food or clothing and culling, in which animals are removed, either physically or lethally, to

\footnotetext{
${ }^{1}$ Submitted on January 19, 2019. Accepted on March 15, 2019. Last changes received on April 30, 2019.

${ }^{2}$ Department of Environmental Sciences and Policy, MSc Program, Johns Hopkins University, Washington, District of Columbia 20036 USA. Email: kpears11@jhu.edu
}

DOI: 10.9784/LEB6(3)Pearson.01

Electronically available on April 30, 2019. Mailed on May 1, 2019. 
reduce their abundance or impact (Yodzis 2001). The practice of culling has been part of human history for centuries, however, in recent years it has become increasingly controversial (van Eeden et al. 2017).

There continue to be cases where a policy of wildlife culling is considered as an option to preserve the physical and financial security of a human community. Such policies can be costly ${ }^{3,4}$, both financially and socio-politically, and as such, they should only be undertaken after careful consideration. The first question that must be asked when contemplating any wildlife cull is - what is the goal of removing these animals? A second question must be - will culling achieve the stated goal? To this end, the goal of the cull must be clearly defined. Finally, because ultimately wildlife culling is a policy decision made on behalf of a human community, the question must be asked - should we take this action?

The case study of the gray seals and white sharks (photos on page 107) on Cape Cod describes a current human-wildlife conflict. In this paper, we will examine available evidence to verify that the perceived competition or threat with the species of concern is scientifically valid. We will consider scientific information from previous culling events and their outcomes to determine whether culling is likely to achieve the perceived goal. The final question, should a cull take place, is ultimately one of policy which in the best case is informed by science.

\section{Case Study: Gray Seals and White Sharks, Cape Cod, Massachusetts}

The southern portion of the northwest Atlantic gray seal population on the east coast of the United States was extirpated due to hunting and bounty programs in the 19th and 20th centuries (Lelli 2009). Gray seals were thought to be extinct in U.S. waters prior to 1958 (Andrews and Mott 1967), and in the 1970's fewer than 13 animals were observed each year in Nantucket Sound (Rough 1995). In $1965^{5}$, Massachusetts instituted protection for the occasionally observed seals which was further expanded by the 1972 Marine Mammal Protection $\mathrm{Act}^{6}$. In the late 1980's, Cape Cod fishermen reported seeing gray seals in the waters around the peninsula. Subsequently, they have seen the population balloon. Since the mid 2000's, fishermen have complained of seals following fishing boats and eating the fish out of nets as they are being brought

\footnotetext{
${ }^{3}$ The footnotes in this paper include a sample of non-peer-reviewed works. They are herein included as they reflect the profound public policy interest culling has.

${ }^{4}$ Morris, S. 2018 (May 1). Badger cull policing cost $£ 800,000$ in one county. The Guardian (US Edition; London, England, UK): https://www.theguardian.com/environment/2018/may/01/badgercull-policing-cost-800000-in-one-county-cheshire

5 The 191st General Court of the Commonwealth of Massachusetts. 2019. Massachusetts Endangered Species Act. M.G.L. https://malegislature.gov/Laws/GeneralLaws/Part//TitleXIX/Chapter131A

${ }^{6}$ Senate and House of Representatives of the United States of America in Congress assembled 1972. Public Law 92-522: Marine Mammal Protection Act of 1972. https://www.govinfo.gov/content/pkg/STATUTE-86/pdf/STATUTE-86-Pg1027.pdf
} 
aboard ${ }^{7}$. Over the past decade, fishermen have suggested that a "controlled harvest" of the seals would be necessary to preserve their catch ${ }^{8}$.

During the same time, another rarely seen species began appearing in the waters off Cape Cod. In 2004, a local fisherman in Woods Hole, Massachusetts saw a white shark ${ }^{9}$ near Naushon Island and brought it to the attention of the Division of Marine Fisheries and shark researcher Greg Skomal. White sharks are known to have a seasonal presence in the deeper waters off the coast of Massachusetts (Skomal et al. 2017), however, such a near-shore sighting was extraordinarily rare at that time. Dr. Skomal attempted to place a satellite tag on the fish in order to learn more about the species movement patterns, seasonal distribution and habitat preferences. ${ }^{10}$ Although the tagging was unsuccessful, publicity surrounding the event stimulated interest, both scientific and popular, in white shark sightings around the Cape and subsequent studies have been undertaken (Skomal et al. 2012). In 2009, a group of five white sharks was sighted and tagged near the coast of Monomoy Island, Massachusetts ${ }^{11}$.

These initial observations were followed by subsequent sightings of white sharks feeding on seals in view of watercraft and beaches. Warning signs were posted at some Cape Cod beaches discouraging swimming in areas populated by seals. In 2012, a swimmer was bitten by a shark a few hundred feet offshore; the injuries were not life-threatening ${ }^{12}$. Those present reportedly observed that there were seals in the area at the time. In the wake of this incident and ongoing shark attacks on seals, various types of "shark spotters" were put in place. Reports of shark sightings would result in beach closures.

Public concern reached a tipping point in September 2018 after two humanshark encounters, one fatal, occurred in the space of a month. On September 15, 2018, a 26-year-old man was surfing in the waters off Wellfleet, Massachusetts when he was bitten by a presumptive white shark and died of his injuries ${ }^{13}$. This

${ }^{7}$ Nickisch, C. 2012 (August 29). Flourishing seals frustrate Cape Cod fishermen. WBUR.org. https://www.wbur.org/news/2012/08/29/cape-seals

${ }^{8}$ Bidgood, J. 2013 (August 16). Thriving in Cape Cod's waters, Gray Seals draw fans and foes. New York Times. https://www.nytimes.com/2013/08/17/us/thriving-in-cape-cods-waters-gray-sealsdraw-fans-and-foes.html

${ }^{9}$ Most scientists refer to these animals as "White Sharks" as there is a single species, Carcharodon carcharias (Linnaeus, 1758), without an indication of subspecies (i.e., "Greater" and "Lesser"). (Martin 2003).

${ }^{10}$ Diodati, P. and D. McKiernan. 2004. Visiting Great White Puts Marine Fisheries to the Test. DMF News 25(Second Quarter-Third Quarter):6-7. https://www.mass.gov/files/documents/2016/08/vx/dmfn-q3-04.pdf

${ }^{11}$ Skomal, G. and J. Chisholm. 2009. Marine fisheries tags White Sharks off Chatham. DMF News 30. https://www.mass.gov/files/2017-08/dmfnq409.pdf

12 Ballou, B. and J. Ellement. 2012 (August 3). Man attacked by great white shark off Ballston Beach in Truro jokes about surviving. Boston.com. https://www.boston.com/uncategorized/noprimarytagmatch/2012/08/03/man-attacked-by-greatwhite-shark-off-ballston-beach-in-truro-jokes-about-surviving

${ }^{13}$ Mervosh, S. 2018 (September 17). Fatal Shark Attack off Cape Cod is First in Massachusetts since 1936. New York Times. https://www.nytimes.com/2018/09/17/us/cape-cod-shark-attack.html 
followed an attack a month prior on another swimmer in the neighboring town of Truro, however, this individual survived the attack ${ }^{14}$. Prior to these events, Cape Cod's beaches, which draw the tourists who provide the majority of seasonal income for local residents, had widely been considered safe from human-shark encounters given that the last fatal attack occurred in 1936 (Gudger 1950).

It has become clear that some form of public safety initiative is required. Local governments have begun investigating technologies for shark-proofing beaches, however, culling the seal population has become the remedy proposed most often in public meetings and newspaper editorials ${ }^{15}$. Despite the complaints of fishermen over the past decade, serious consideration of a policy of culling the gray seals has occurred only after the recent shark bite fatality ${ }^{16,17}$. Thus, the primary goal of a gray seal cull on Cape Cod would be to reduce the risk of human-white shark encounters.

The public call for a gray seal cull on Cape Cod rests on the assumption that killing seals would eliminate the shark's source of food and they would move on to other more bountiful waters. However, given the complexity of marine ecosystems and the broad ranges of its apex and mesopredators, acting based on such a simple assumption could possibly worsen rather than improve the risk to beachgoers. A few scientists have weighed in with opinions as to the potential outcome of a seal cull, including the possibility of an increase in human-shark encounters with the removal of their preferred prey. Dr. Sean Hayes, Chief of the Protected Species Branch at NOAA/NEFSC speaking to a reporter noted that despite increasing seal and shark populations along California's coast, the number of shark bites on humans has remained stable ${ }^{18}$. Hayes suggests that the presence of an abundant seal population in fact results in fewer mistaken attacks on humans ${ }^{19}$.

${ }^{14}$ Price, L. 2018 (August 16). Shark bite: man suffers 'deep puncture wounds' in attack at Cape Cod beach. USA Today. https://www.wwltv.com/article/news/nation-now/shark-bite-man-suffers-deeppuncture-wounds-in-attack-at-cape-cod-beach/465-125f9a13-ceb3-4417-a444-24b063187599

${ }_{15}$ Wood, T. 2018 (October 17). Can containing seals help solve the shark problem? The Cape Cod Chronicle , https://capecodchronicle.com/en/5342/chatham/3642/Can-Containing-Seals-HelpSolve-The-Shark-Problem-Sharks-seals.htm

${ }^{16}$ Macdonald, M. and M. Gere. 2018 (September 18). Cape Cod officials call for action after fatal shark attack. $w w w$. WPRI.com, https://www.wpri.com/news/local-news/cape-cod-officials-callfor-action-after-fatal-shark-attack/1456416597

${ }_{17}$ Cape Cod Today Staff. 2018 (September 27). County commissioner Beaty reiterates call to cull seal population. $\quad$ www.capecodtoday.com https://www.capecodtoday.com/article/2018/09/27/242463-County-Commissioner-BeatyReiterates-Call-Cull-Seal-Population

18 Mizes-Tan, S. 2018 (September 18). Cape Cod looks to improve beach safety after fatal shark attack. WGBH.org , https://www.wgbh.org/news/local-news/2018/09/20/cape-cod-looks-toimprove-beach-safety-after-fatal-shark-attack

19 Mizes-Tan, S. 2018 (September 18). Cape Cod looks to improve beach safety after fatal shark attack. WGBH.org , https://www.wgbh.org/news/local-news/2018/09/20/cape-cod-looks-toimprove-beach-safety-after-fatal-shark-attack 
Scientists are currently working to a obtain additional data on the biology and ecology of gray seals and white sharks and the ecosystem they share. A tagging and tracking study of the white shark has been undertaken by the Massachusetts Marine Fisheries Service and the University of Massachusetts (Skomal et al. 2017). Gray seals are being studied and tracked to learn more about their migratory behavior and role in local ecosystems (Moxley et al. 2017). Towns on the Outer Cape along with the Atlantic White Shark Conservancy and the Cape Cod National Seashore have recently commissioned a study on options for mitigating the risk of human-shark encounter in local waters ${ }^{20}$. However, some policy action may be demanded by concerned local citizens sooner than current studies can be completed ${ }^{21}$.

It may be possible to provide some scientific guidance prior to the completion of the ongoing studies. The geographic and ecological setting of the human-wildlife conflict can be described and biological information about gray seals and white sharks compiled to identify parameters that could be relevant in the consideration of a cull. Current population data for gray (or grey) seals, Halichoerus grypus (Fabricius, 1791) (Carnivora: Phocidae), and white sharks, Carcharodon carcharias (Linnaeus, 1758) (Chondrichthyes: Lamnidae), can be examined to validate local perceptions of population growth. The scientific literature on culling can be reviewed to provide guidance about the possible outcomes associated with culling wildlife in a variety of settings. If possible, criteria can be identified under which culling has been used successfully and lessons learned when it has not. These criteria, informed by the geography, ecology and biology, will be applied to predict the possible outcomes of a potential gray seal cull on Cape Cod which could aid policymakers in their decision process.

\section{Methods}

Literature Search. The first part of the study consisted of a comprehensive qualitative literature search on the biology and ecology of gray seals and white sharks emphasizing the Northwest Atlantic ecosystem. The Johns Hopkins University Library, PubMed, and Google Scholar online databases were queried using the search terms "gray seal" and "white shark". Returned manuscripts were compiled in a database and sorted by species. Citations within those articles were searched to identify additional pertinent references, including book chapters. Articles citing those manuscripts were searched to identify additional references. Pertinent media reports were sourced for articles on the case study.

\footnotetext{
${ }^{20}$ Wood, T. 2019 (February 20). Study of ways to improve shark safety gets underway. The Cape Cod Chronicle. https://capecodchronicle.com/en/5408/chatham/4109/Study-Of-Ways-ToImprove-Shark-Safety-Gets-Underway-Sharks.htm

${ }_{21}$ Marcelo, P. 2019 (February 24). After fatal shark attack on Cape Cod, some complain of slow response. Bangor Daily News. https://bangordailynews.com/2019/02/24/news/new-england/afterfatal-shark-attack-on-cape-cod-some-complain-of-slow-response/
} 
Personal communications and unpublished reports were included for current active ongoing studies. Notes from public meetings in different locations on the south coast of Cape Cod were included.

The second part of the study consisted of a comprehensive qualitative literature search on the science and practice of culling, and a review of prior culling events. The same databases were queried using the search terms "wildlife culling", "wildlife population management", "marine mammal culling". The method described above was used to manage and review the returned manuscripts. The culling studies were sorted into those that pertain to marine mammals and those that pertain to other taxa. Vertebrate taxa only were included and mammalian studies, if available, were prioritized. Culling of domesticated animals and livestock and culling events occurring greater than 10 years prior were excluded. The latter exclusion was made to reflect contemporary approaches to the practice of culling regarding methodology, tracking, and sociopolitical concerns.

Population Data. Evaluating the demographic status of marine vertebrates is challenging at best. For this study, counts of seal and shark populations were compiled from multiple sources including NOAA, literature references, and unpublished data from the Massachusetts Marine Fisheries Service.

Gray Seal Counts. Pup counts from breeding colonies can be used in a population model to estimate the total population size utilizing a maximum likelihood model (Bowen et al. 2003). In general, the overall population size is between 3.5-4.0 times the pup production (Hall and Thompson 2009). Pupping data from 1991-2000 were obtained from Wood LaFond (2009) and those from 2001-2015 were obtained from the National Oceanic and Atmospheric Administration (NOAA).

White Shark Counts: White shark counts are based on sighting data. Between 1987-2009, Skomal et al. (2012) compiled and classified white shark sightings around Cape Cod according to specific criteria:

1. Class A: Positive identification based on valid description, dead specimen, and/or photo/video support.

2. Class B: Accurate description, but no photographic evidence.

3. Class C: Suspect description, no corroborative support.

4. Class F: False report or misidentification (witness acknowledges after being shown photos, Skomal et al. 2012).

White shark population data for 2013-2018 are currently unpublished. The Massachusetts Division of Marine Fishes in conjunction with the Atlantic White Shark Conservancy are conducting a 5-year tagging and tracking study of white 
sharks around Cape Cod. Data from 2014, 2015, and 2016 were available from public meeting presentations by Dr. Skomal ${ }^{22}$.

\section{Results \\ Geographical, Biological, and Ecological Setting of the Human-Wildlife Conflict}

The geographic range of gray seals in the northwest Atlantic extends from the coast of Labrador to North Carolina, however, south of Massachusetts, they are found only seasonally or as strandings (Hayes et al. 2018). This range spans the international boundary between the United States and Canada and thus is not subject to the same wildlife conservation policies and laws throughout its extent. The year-round population of Northwest Atlantic gray seals is found between Labrador and Cape Cod, Massachusetts (Hayes et al. 2018). The entire population is estimated to be in excess of 500,000 adults (Hayes et al. 2018). The most prolific pupping site in the northeastern Canadian waters is the Sable Island breeding aggregation (DFO 2017). In U.S. waters, the Muskeget/Monomoy breeding sites are the most prolific followed by Seal Island off the coast of Maine (Hayes et al. 2018). Genetic analyses indicate that the breeding colonies in Canadian waters and those in the U.S. form a single, open population (Wood et al. 2011). Tagging studies have documented individual gray seals moving between Canada and Cape Cod (Rough 1995).

Gray seals are the largest seals found in the waters around Cape Cod. Throughout much of the year, they spend their days foraging and resting on the beaches of the outer Cape and islands. In January and February, gray seals haul out in large groups on Muskeget and Monomoy Islands where they gather for pupping and mating (Ampela 2009). Females give birth to a single pup that is nursed for 2-3 weeks (Hall and Thompson 2009). Mothers fast throughout the weaning period, remaining on land with their pups and relying entirely on stored nutrients; thus, they are often cited as classic examples of capital breeding (Houston et al. 2007). After weaning, mothers will mate before returning to the sea to forage, leaving their pups to fend for themselves for an additional three weeks (Hall and Thompson 2009). Gray seal females exhibit a high degree of fidelity to their breeding sites and will predictably return to the islands in a year to pup and breed again. (Pomeroy et al. 2000). Gestation is 11.5 months including an up to 3-month delay in implantation. Termed embryonic diapause, this phenomenon allows gray seals to give birth at the same time every year (Atkinson 1997).

Gray seal pups are born with white coats of lanugo hair which makes them easy to identify (Hall and Thompson 2009). They retain their lanugo for a few weeks at which time they molt, losing their white coat and acquiring their gray

22 Skomal, G. 2018 (October 30) Cape Cod Community Shark Information Session. Wellfleet Elementary School. Wellfleet, Massachusetts, USA. This meeting was presented in full on local television, https://vimeo.com/298183014 
patterning (Hall and Thompson 2009). After weaning, pups remain on land for up to three weeks developing the necessary muscle tone and chemistry to be successful divers (Noren et al. 2005). They do not eat during this period and may lose up to $25 \%$ of their body mass before they enter the sea to feed (Noren et al. 2005). The periodicity of the reproductive cycle as well as the isolation of the pups in the post-weaning period could be an important consideration should a cull be undertaken.

When the pups do enter the sea, they become part of a complex ecosystem. This region is characterized by a relatively shallow, broad continental shelf and is an area of high biological productivity due to a zone of upwelling produced by the intersection of the northward Gulf Stream current and the southward Labrador Current. These nutrient-rich waters support a species-rich food web with significantly greater connectivity than other webs of the same size as can be seen in Figure 3 (Link 2002). The large number of species interactions described by this food web means that few if any of them reach the magnitude to alter the overall feeding dynamics (Dunne et al. 2004). In other words, in the absence of significant human perturbation - such as overfishing - no single species in the system is either directly dependent or directly impacted by the population dynamics of another species (Link 2002). This conclusion has direct relevance to the fallacious attribution of declines in stocks of fiscally important fishes solely to increases in seal or other marine mammal populations.

Gray seals are represented in node 76 (seals) in Figure 3 and white sharks in node 78 (migratory sharks). Both species are predators, occupying the highest trophic level in the food web. This is an important consideration for a proposed cull since changes in the abundance of a higher-order consumer can create a trophic cascade that may influence species interactions downward through the food web destabilizing the ecosystem (Ripple et al. 2016).

It is also worth noting that gray seals share the node with three other species of seals - the harbor seal, Phoca vitulina Linnaeus, 1758; harp seal, Pagophilus groenlandicus (Erxleben, 1777); and hooded seal, Cystophora cristata (Erxleben, 1777). The latter two are among the so-called "ice-breeding seals"; those that live and reproduce primarily on the northern Atlantic sea ice (Davis et al. 2008). Ice-breeding seals are only periodically seen on Cape Cod, however, harbor seals and gray seals can be found occupying communal haul-out sites on the Cape and Islands (Pace et al. 2019).

Like the larger gray seal, harbor seals were hunted through the last century until state and federal protections were instituted (Lelli et al. 2009). While hunting caused gray seals to be extirpated from New England shores, harbor seals maintained a small presence in the Gulf of Maine (Katona et al. 1993). The populations of both species in New England waters have increased in the last quarter of the twentieth century sympatrically coincident with passage of the Marine Mammal Protection Act in the United States (Hammill et al. 2017, Gilbert et al. 2005). At last estimate, harbor seals numbered approximately 
76,000 on the Maine coast and gray seals approximately 30-50,000 on Cape Cod (Moxley et al. 2017). However, gray seals have established more robust pupping sites in southern New England than have harbor seals (Hayes et al. 2018). While the gray seal population has continued to grow, there are some indicators that the harbor seal population may be stable or declining (Johnston et al. 2015). Johnston notes that on Cape Cod, some former harbor seal haul-outs are now populated with gray seals. Studies have suggested that gray seals are putting pressure on harbor seals; gray seals have been observed to aggressively displace harbor seals from some haul-outs (Murray 2008).

As Figure 3 demonstrates, there is considerable overlap in the diet of harbor and gray seals in this area. Both species feed at multiple trophic levels including fish, cephalopods, crustaceans, and, to a lesser extent, seabirds. However, the sand eel or sand lance (Ammodytidae) makes up more than half of the diet of both species in Cape Cod waters (Hall and Thompson 2009, Payne and Selzer 1989). This suggests that the culling of gray seals could open space in a niche that harbor seals could realize. An important question would be whether the local harbor seal population would increase in the setting of a gray seal cull thus negating any potential effect of prey removal on the white shark population.

White sharks, Carcharodon carcharias, are the largest predatory fish in the sea. They are found worldwide in temperate and subtropical regions (Bruce 2008) White sharks are endothermic; their circulatory system is adapted to conserve the heat generated by their working muscles (Bruce 2008). This allows them to range into colder waters in search of prey. White sharks are believed to live for 30 or more years (Hamady et al. 2014). They are characterized by bulky torpedo-shaped bodies with a sharply pointed snout and a white underbelly. They may reach lengths of over 6 meters and weighing up to 2300 kilograms (Castro 2012). White Shark reproduction is ovoviviparous with a gestation period of 12-18 months producing litters of 2-10 juveniles (Bruce 2008). Juveniles are thought to spend the first few year or more of their lives in "nurseries", shallow coastal areas in which juvenile sharks can develop with a degree of protection from predation (Heupel et al. 2007). One such nursery has recently been suggested to exist off of the coast of Long Island (Curtis et al. 2018).The adult white shark diet is diverse, consisting of other sharks, seals, sea lions, dolphins and whale carcasses (Bruce 2008), however, juveniles feed mostly on fish and add marine mammals to their diet when they reach $341 \mathrm{~cm}$ in length (Estrada et al. 2006). 


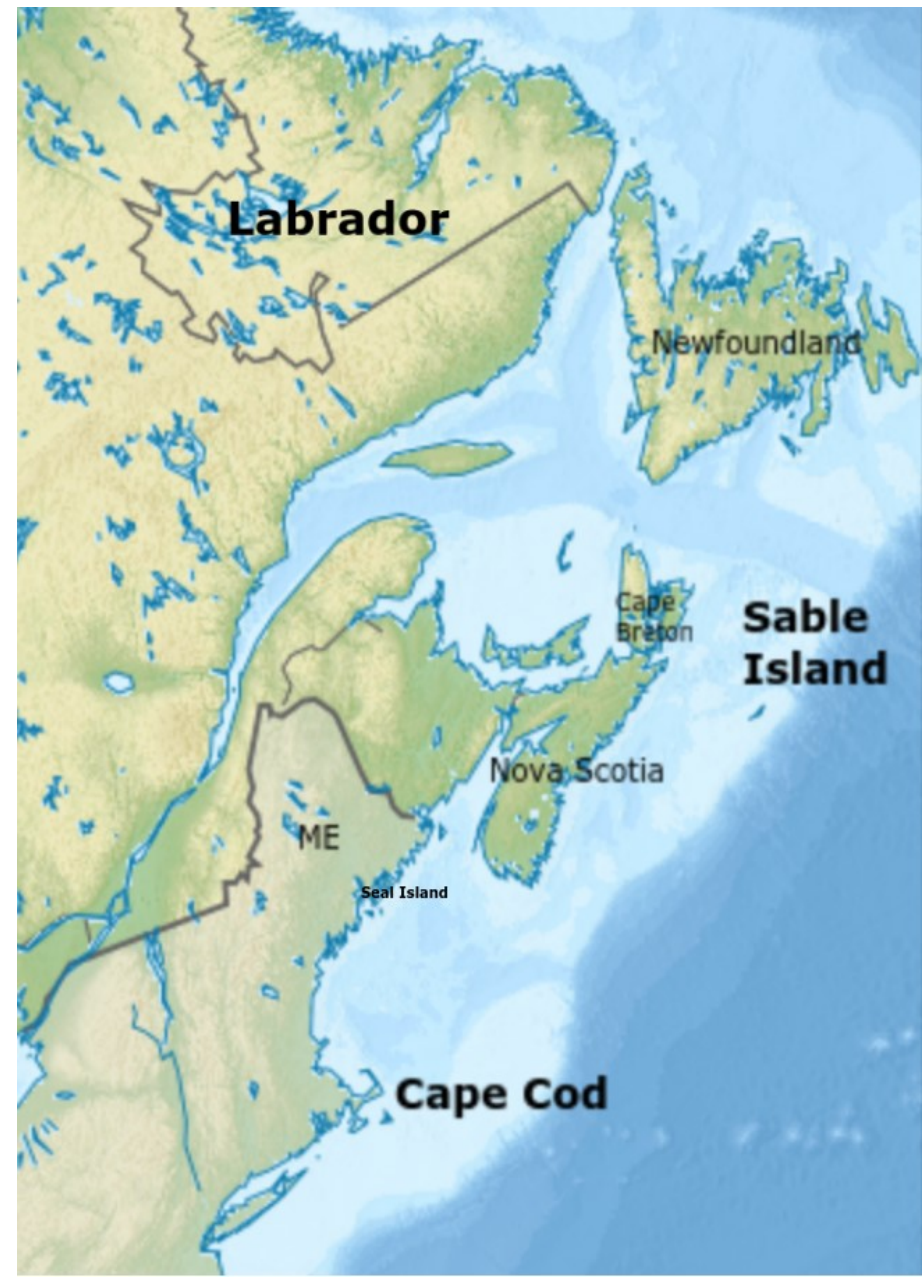

Figure 1. Northeast U.S. and Canadian Continental Shelf Ecosystem: Areas of interest mentioned this paper are labeled. https://en.wikipedia.org/wiki/Sable Island National Park Reserve\#/media/File:Relief map of Canada.png 


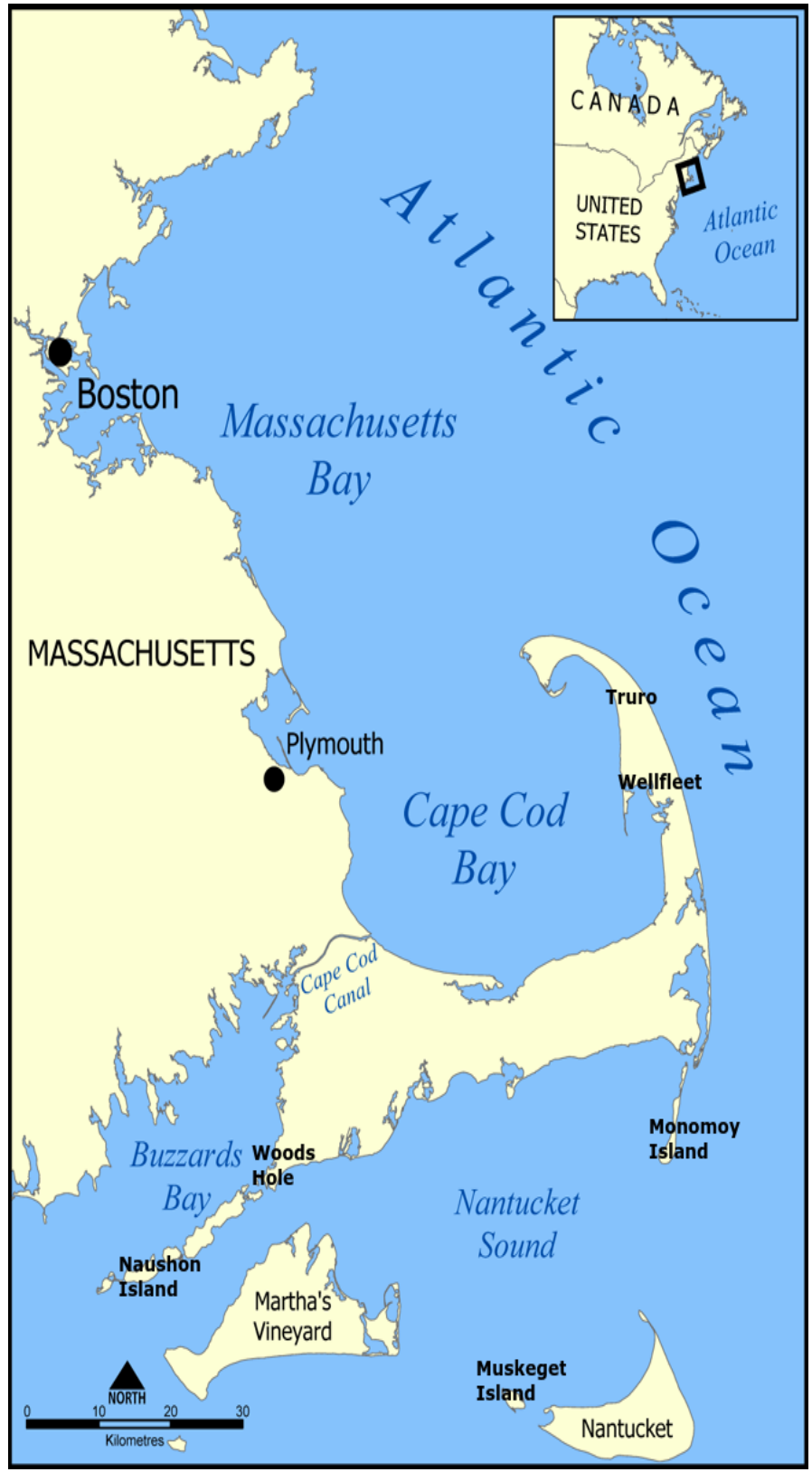

Figure 2. Cape Cod and the Islands highlighting areas of interest mentioned in this paper. https://en.wikipedia.org/wiki/Portal:Cape_Cod_and the Islands\#/media/File:Cape_Cod_Bay_m ap.png 


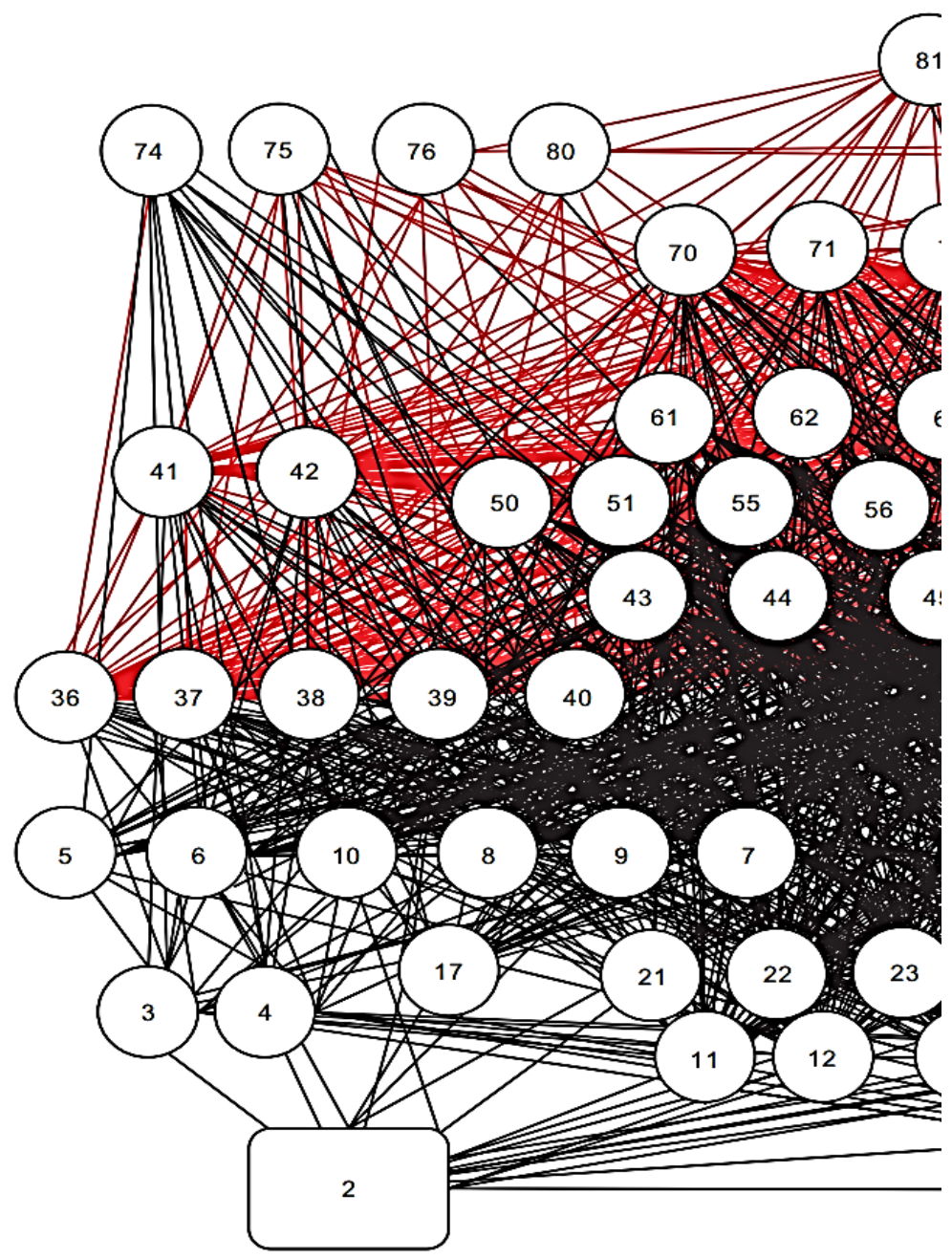

Figure 3. Species and links of the northwest Atlantic food web (Link 2002). This tangled "bird's nest" represents interactions at the approximate trophic level of each species, with increasing trophic level towards the top of the web. The left side of the web generally typifies pelagic organisms, and the right to middle represents more benthic/demersally (just above the benthic zone)-oriented organisms. Red lines indicate predation on fish. 1=detritus, 2=phytoplankton, 3=Calanus sp., 4=other copepods, $5=$ ctenophores, $6=$ chaetognathans (i.e., arrow worms), $7=$ jellyfish, $8=$ =uphausiids, 9=Crangon sp., 10=mysids, 11=pandalids, 12=other decapods, 13=gammarids, 14 =hyperiids, 15 =caprellids, 16 =isopods, $17=$ =pteropods, $18=$ cumaceans, $19=$ mantis shrimps, $20=$ tunicates, $21=$ poriferans (sponges), $22=$ cancer 


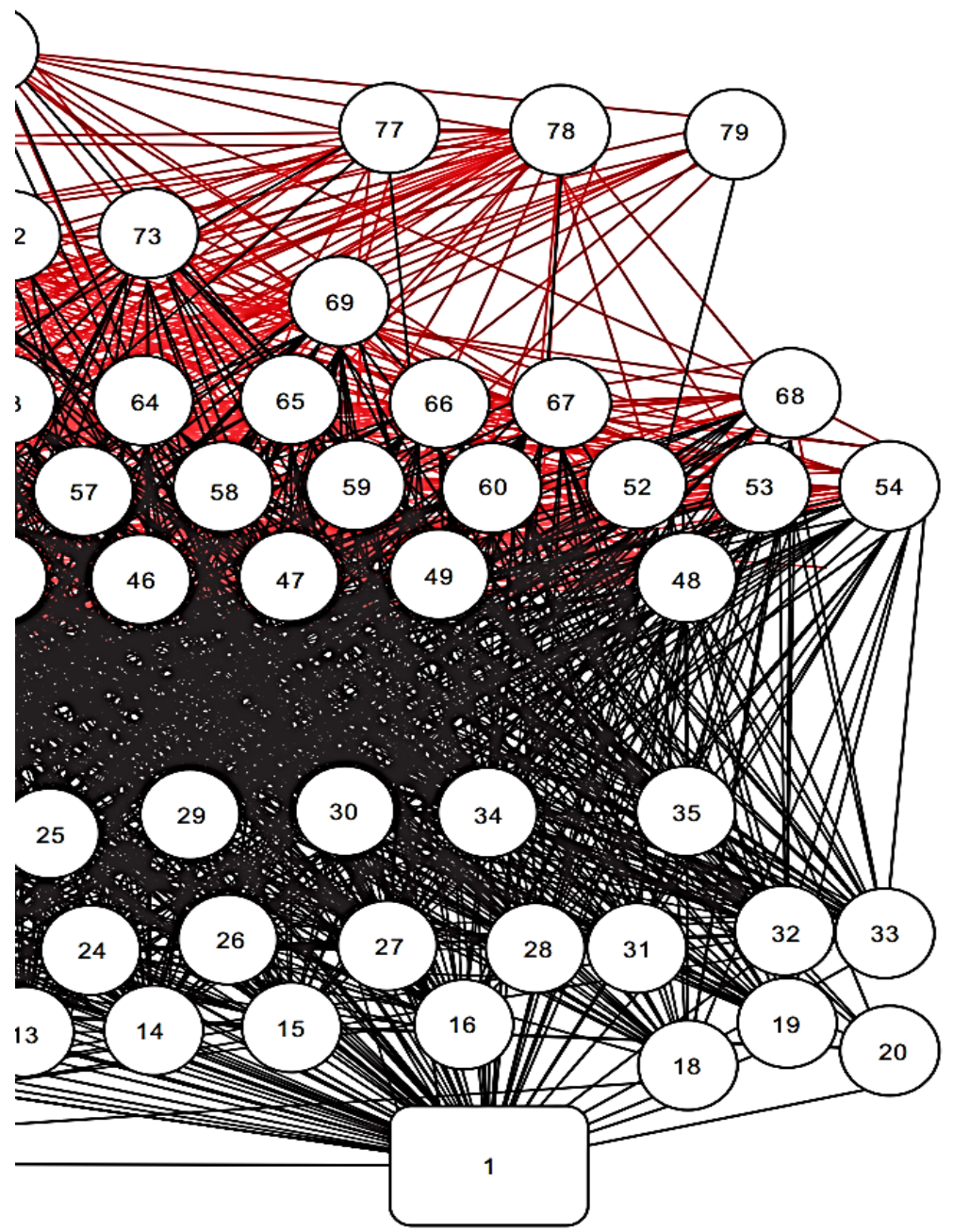

crabs, $23=$ other crabs, $24=$ lobsters, $25=$ hydroids, $26=$ corals and anemones, $29=$ starfish, $30=$ brittle stars, $31=$ sea cucumbers, $32=$ scallops, $33=$ clams and mussels, $34=$ snails, 35=urchins, 36=sand lances, 37=Atlantic herring, 38=alewife, 39=Atlantic mackerels, 40=butterfish, 41=loligo, 42=illex, 43=pollock, 44=silver hake, 45=spotted hake, 46=white hake, $47=$ red hake, $48=$ Atlantic cod, $49=$ haddock, $50=$ sea raven, 51=longhorn sculpin, $52=$ little skate, $53=$ winter skate, $54=$ thorny skate, $55=$ ocean pout, $56=$ cusk, $57=$ wolfish, 58=cunner, $59=$ sea robins, $60=$ redfish, $61=$ yellowtail flounder, $67=$ American plaice, 68=American halibut, 69=smooth dogfish, 70=spiny dogfish, 71=goosefish, 72=weakfish, $73=$ bluefish, $74=$ baleen whales, $75=$ toothed whales and porpoises, $76=$ seals, $77=$ migratory scombroids, $78=$ migratory sharks, $79=$ migratory billfish, $80=$ birds, $81=$ humans. Image reprinted without changes under "Creative Commons by Attribution License (CC-BY)" for open access use. Caption includes edits for clarity. 
An understanding of the feeding preferences and behaviors of white sharks is critical to the question of whether to cull gray seals. The proposed cull is predicated on the assumption that the growing seal population is drawing sharks to the area to feed on abundant prey. Skomal et al. (2012) demonstrated an increase in white shark sightings in response to increasing prey population abundance. In a stomach contents study, Hussey et al. (2012) found that white sharks preferred "large-bodied, energetically valuable prey" such as seals, and that the abundance of preferred prey could influence the movement and residency of individuals over $200 \mathrm{~cm}$ in length. These studies might seem to support the assumption behind the seal cull, however, a study in California found that human-white shark encounters in fact decreased in the setting of a recovering seal population (Ferretti et al. 2015).

\section{Population Data}

Atlantic Gray Seal pup counts on Muskeget Island plotted against pupping year is shown in Figure 4. Population trends for Gray Seals are best represented by pup counts (Lonergan et al. 2011). Currently, an estimated 30,000 to 50,000 gray seals inhabit Cape Cod at some point during the year (Moxley et al. 2017).

\section{Muskeget Island Seal Pup Counts by Year - Exponential Fit}

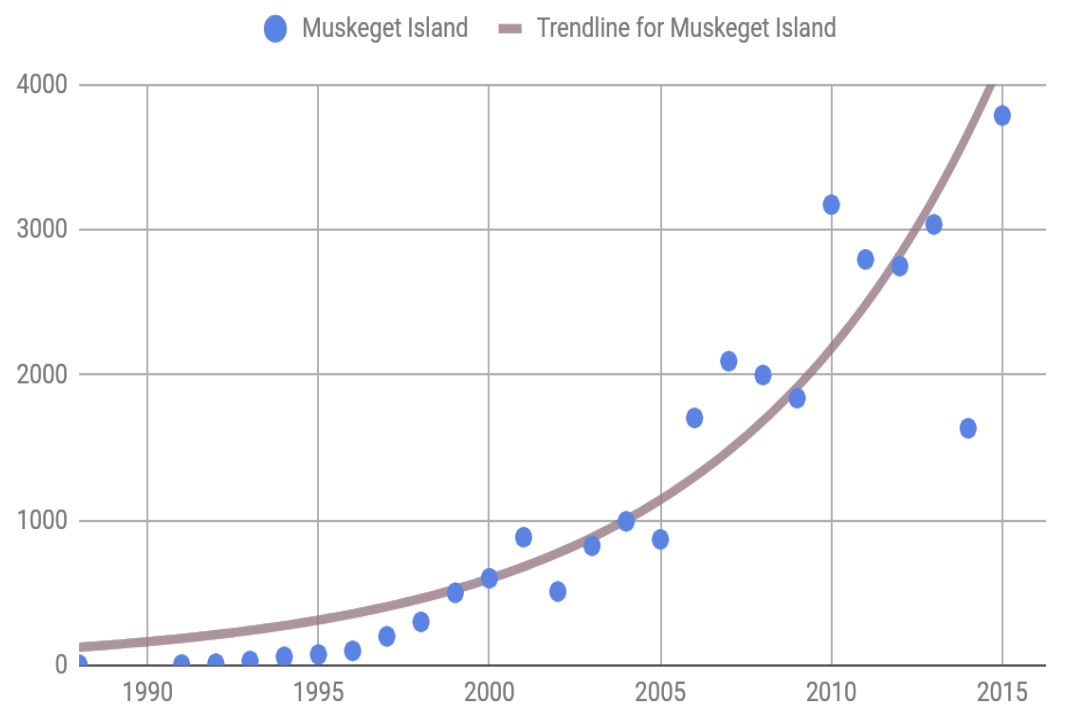

Figure 4. Muskeget Island Annual Gray Seal Pupping Counts. Data sources: 1991-2000 (Wood LaFond 2009), 2001-2015 (Waring et al. 2001-2015).

A best-fit curve was calculated using Google Sheets. The gray seal population as extrapolated from pup counts shows exponential growth over the 
period sampled. This magnitude of population growth is best represented by pupping rates of resident females being augmented by significant immigration from the Sable Island population (Wood LaFond 2009). Exponential growth was observed in the Sable Island, Nova Scotia gray seal population where longitudinal counts have been performed since the early 1960's (Bowen et al. 2003). However, recent counts suggest that population growth may be slowing (Bowen et al. 2007, Hammill et al. 2017). Ongoing growth of the gray seal population on Cape Cod may indicate that the population has not yet reached the carrying capacity of the ecosystem for this species.

\section{White Shark Sightings by Year}

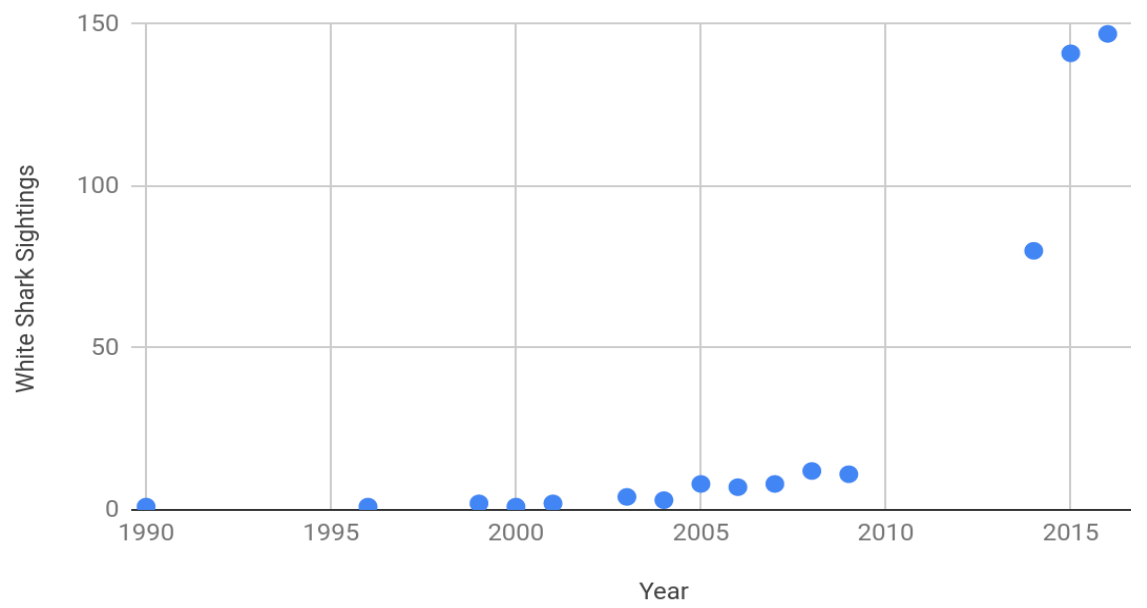

Figure 5. White Shark Sightings Around Cape Cod. Sources: 1987-2009 (Skomal 2012), 2014-2018 (Skomal $\left.{ }^{23}\right)$

Shark sighting data are plotted above. An increase in sightings is suggested, however, the differing methods of data collection do not allow them to be considered as a statistically valid time series. In addition, the scarcity of these data precludes drawing definitive conclusions from this representation.

While both the seal and shark data show similar trends in abundance, it would be premature to propose a causal relationship between them. It is possible that the shark population may not be increasing in size; rather, an existing population may be redistributing to coastal waters where a food supply is

${ }^{23}$ Skomal, G. 2018 (October 30) Cape Cod Community Shark Information Session. Wellfleet Elementary School. Wellfleet, Massachusetts, USA. This meeting was presented in full on local television, https://vimeo.com/298183014 
plentiful. The recently tagging study, which includes over 150 sharks, will hopefully provide more information about the population size and habits ${ }^{24}$.

If, as has been suggested that white sharks exhibit prey-dependent population dynamics (Skomal et al. 2012, Hussey et al. 2012), these data would not be inconsistent with that assumption. The increase in shark sightings appears to follow the increase in seal abundance after a lag period. Although the data are insufficient to support any conclusions, the natural course of this dynamic would be a decrease in both seal and shark populations regardless of human intervention.

\section{Culling: Review of the Literature and Ecological Outcomes}

The population data cited above demonstrate that there is adequate scientific evidence to confirm that the gray seal population in the northwest Atlantic is continuing to increase both overall and specifically on Cape Cod. Growth in the Cape population is likely occurring both through reproduction and immigration from the north. There is also some evidence to support the hypothesis that the population of white sharks has increased in the near-shore waters around Cape Cod. In this section, the scientific evidence from wildlife culling for population control will be reviewed, with special attention to unforeseen outcomes.

For the purposes of this study, culling was defined as the removal, lethal or otherwise, of animals from wildlife populations. Historically, most wildlife culling has been performed without rigorous scientific observation and analysis taking place (Eklund et al. 2017). Possible outcomes of the proposed cull may be identified from a review of the scientific literature, however, it will be necessary to look not just at examples with direct application to the current question of the Cape Cod gray seals but at any study in which data collection was sufficient to provide insight into the ecological effects of culling.

\section{Indications for Culling}

The scientific literature on wildlife culling can be sorted into four general categories based upon the desired outcome within the ecosystem of interest:

\section{Culling for disease control}

a. Animal disease

b. Zoonoses

\section{Culling for ecosystem stability}

a. Protection of threatened species

b. Balancing resource competition

${ }^{24}$ Skomal, G. 2018 (October 30) Cape Cod Community Shark Information Session. Wellfleet Elementary School. Wellfleet, Massachusetts, USA. This meeting was presented in full on local television, https://vimeo.com/298183014 


\section{Selective Culling}

a. Culling by age or gender

b. Culling of problem individuals

\section{Culling to remove invasive species}

Each of these will be discussed below citing examples from marine mammal events, where available, and from other taxa where outcome data can inform a discussion of the possible outcome of the proposed Cape Cod gray seal cull.

\section{Culling for Disease Control}

Culling for disease control, both animal disease and zoonoses, has been carried out around the globe but its effectiveness is debatable. Culling for the control of wildlife-only diseases represents a distinct challenge from that of culling for animal diseases that may be transmitted from wildlife to livestock. Zoonoses - pathogens transmitted to humans through animal reservoirs - present yet another set of challenges.

Culling to control diseases of wildlife. Although not an indication for culling the gray seals, it is possible that the ecological parameters of culling for disease control could prove useful in the discussion. Wild animals can be affected by diseases that cause serious harm to their own populations in addition to acting as vectors for diseases that can be spread to cultivated livestock or other wildlife. Examples of the first case would be a cull of infected Tasmanian devils, Sarcophilus harrisii, (Boitard 1841) a threatened species that is facing possible extinction due to an infectious cancer, Devil Facial Tumor Disease (DFTD). In this case, selective culling of infected individuals did not affect the spread of the disease in the remaining population (Lachish et al. 2010). The failure of this culling program is thought to be due to the fact the necessary removal rate of infected individuals is too high to be achieved while simultaneously preserving the species (Beeton and McCallum 2011). Current management of DFTD consists of segregating a breeding population of uninfected individuals for possible rewilding and pursuing a vaccine against the disease (Woods et al. 2018). By contrast, a cull of white-tailed deer, Odocoileus virginianus (Zimmermann, 1780), in Illinois was successful at keeping the rate of chronic wasting disease, the deer equivalent of mad cow disease, at one percent while the rates in unculled areas reached 5 percent (Manjerovic et al. 2014). In this cull, approximately 200,000 animals were killed over a 10-year period of an estimated population of 800,000 or a 25 percent cull. This study demonstrates that culling for control of diseases of wild animals can be successful if a significant percentage of the population can be removed without compromising the remaining population. Culls like that of the white-tailed deer, 
must be performed on an annual basis in order to be effective. One-time and episodic culls are likely to be less successful.

Culling to prevent disease transmission from wildlife to livestock. There are abundant examples of wildlife culling where the goal is to prevent transmission of a disease from wildlife to livestock. A recent and highly controversial example is that of badgers, Meles meles (Linnaeus, 1758), in the United Kingdom (McDonald 2014). Badgers are a reservoir for bovine tuberculosis (bTB) which when spread to cattle results in loss to market of all infected stock. Approximately 5 percent of the badger population in the UK was culled (Judge et al. 2017). Results of the Randomized Badger Culling Trial demonstrated that while bTB incidence in cattle did decrease in the culled areas, it was associated with increases in the disease in surrounding unculled areas (Bielby et al. 2016). Social perturbations within the badger community were felt to be responsible for the observation; badgers are highly territorial animals and in the undisturbed state tend to remain in their own ranges and communities. The perturbation caused by culling caused badgers to range outside of their familiar home territories, mix with other badger communities and increase the spread of bTB (Bleicher 2017). In effect, social stability of badger communities functions to limit the spread of disease (McDonald 2014). Current management strategies are moving away from culling and towards vaccination trials (Aznar et al. 2018).

Similarly, disappointing results were obtained from a bison, Bison bison (Linnaeus 1758) cull in Yellowstone Park aimed at reducing the transmission of brucellosis to cattle stock. While initial post-cull studies showed adjoining states becoming brucellosis-free, the success was short-lived and within two years, brucellosis rates had increased; this time an increasing elk population was the vector (White et al. 2011; Gortazar et al. 2014). This study demonstrates a basic tenet of ecology: when reducing competition for resources in an area corresponding to the fundamental niche of a species, the population will expand its "realized niche" accordingly (Singer 2016). In this case, elk population expansion brought brucellosis with it, thus defeating the purpose of the cull.

Culling to prevent human disease. Wildlife culling to prevent transmission of human disease is an ongoing strategy with mixed results. In the United States, White-tailed deer are culled with the goal of decreasing the incidence of Lyme disease in humans (Telford 2017). Despite multiple attempts in various locations, the only successes have been in areas where a population has been extirpated. On Monhegan Island off the coast of Maine, an entire herd was culled. Since that event, Lyme-bearing ticks have not been found on the island (Kugeler et al. 2016).

Rabies elimination, however, has been extraordinarily successful across Europe through population control of the fox, Vulpes vulpes (Linnaeus, 1758), host. Early eradication attempts utilizing only culling to reduce fox numbers met with limited success and eventually these culls were observed to disrupt the 
social system of foxes. Increasing contact rates with other fox populations led to increasing disease incidence (Freuling et al. 2013). Ultimately, success was achieved with the development of an oral spaying agent that was delivered through food bait, combined with highly selective culling in remote areas.

Ecological outcomes of culling for disease control. To summarize, a review of the recent scientific literature on wildlife culling to prevent disease transmission shows mixed success for culling of infected or reservoir species. Where there has been reduction of the infection rate, the cull may need to approach $100 \%$ or extirpation of the reservoir species. Culling has been complicated in both badgers and foxes by social perturbation that has created an outcome diametrically opposite of the goal of the cull.

The applicability of culls for disease control to the proposed Atlantic gray seal scenario lies principally in their ecological outcomes, which should be kept in mind when considering any wildlife cull. First, extirpation will not be possible as the population is continuous through coastal New England and Canada and migration in addition to reproduction will likely replace those that are culled. Like the deer wasting disease example, annual culling would be needed to maintain any population control. Second, gray seals are relatively intelligent animals as demonstrated by their capacity for vocal learning (Shapiro et al. 2004, Stansbury et al. 2015) and as such likely possess a level of threat awareness at least as high as a badger or a fox. The likelihood that widespread culling would be perceived as a threat by the seals is high, potentially causing them to move to other areas of Cape Cod and increasing the risk of human-shark encounters in those currently unaffected areas. In addition, there are also harbor seals in the waters of Cape Cod which, like the elk in Yellowstone, could occupy the niche opened by the gray seal cull.

The finding that oral-agent spaying was as or more successful in controlling an unconstrained population of terrestrial mammals presents an interesting option. In 2012, Canadian lawmakers considered the use of a long-acting contraceptive agent, porcine zona pellucida (PZP) vaccine, which has been shown to reduce pup production by up to 90 percent (Brown et al. 1997), in the Sable Island gray seal population. Ultimately, they determined that the cost and logistics of parenteral vaccine administration would be prohibitive (Manning and Hubley 2012). There is currently no species-specific oral spaying agent for seals, however, a drug, 4-vinylcyclohexene diepoxide (VCD-trade name "Chemspay") which induces infertility with single-dose oral administration, is in the FDA approval and patent process for dogs (Mayer and Dyer 2018). If the agent is found to be safe and effective, oral spaying could possibly work as an agent for population control in gray seals and a canine formulation may be adequate given the phylogenetic kinship between seals and dogs (Vila and Leonard 2012). 


\section{Culling for Ecosystem Stability}

A stable ecosystem represents a sustainable habitat of interdependent animals, plants, and microorganisms and their environment. Stable ecosystems display efficient energy and material cycling and interconnectedness between trophic levels (Saint-Béat et al. 2015). Ecosystem scenarios for which culling events have been undertaken include the protection of threatened species and intervention in resource competition scenarios. Too often, culls are proposed when human exploitation of resources has led to these imbalances.

The culling of marine mammals has a long history and has been undertaken in many parts of the world with the goal in large part of protecting fish stocks for human consumption, however, the data do not support this practice (Lavigne 2003, Morissette et al. 2012, Corkeron 2009). In marine habitats, the mortality of fish beyond the juvenile stage is primarily caused by birds, mammals, and fisheries, however, the largest predator of fish is other fish (Yodzis 2001). Marine mammals are more visible than other predators and may be seen damaging fishing gear which gives them a reputation for being a more significant threat to fish stocks than they truly are.

Culling to protect threatened species. In the case of the Cape Cod gray seals, the proposal would be to cull a prey animal to eliminate its predator from at least the near-shore habitat. There are two interesting cases in the literature in which prey were culled to affect the population of a predator; in both cases, the cull was undertaken to protect a threatened species. In the southern part of British Columbia, the Woodland Caribou, Rangifer tarandus caribou (Gmelin 1788), has declined and a moose, Alces alces (Linnaeus, 1758), population has migrated from adjacent areas to realize available habitat space (Seip 1992). The influx of moose has propped up the dwindling wolf, Canis lupus (Linnaeus, 1758), population which preys on both moose and caribou (Seip 2008). This has resulted in caribou becoming increasingly threatened due to ongoing wolf predation. However, the wolf population in the area is not overly robust and culling wolves was not considered to be an option; instead, the moose population was subjected to a 70 percent cull and wolf numbers declined in the area (Serrouya et al. 2011). Caribou adult survival increased from 0.78 to 0.88 . This observed stabilization of the caribou population is comparable to that achieved in studies using intensive wolf control (Serrouya et al. 2017). Wolf abundance declined in parallel with the declining moose population.

A study in northern Norway of culling to protect a threatened species, Brown Lake Trout, Salmo trutta (Linnaeus, 1758), that had been subject to overfishing. As trout numbers decreased, conservation managers attempted to provide them with an excess of food by introducing Arctic Char, Salvelinus alpinus (Linnaeus, 1758), into the lake to stimulate trout population growth (Persson et al. 2007). The char population flourished but the trout population did not. An $80 \%$ cull of older char was carried out and the trout population recovered (Klemetsen et al. 2002). Persson et al. (2007) postulated that culling 
the larger, older char from the lake maintained the availability of smaller sized prey for the trout while decreasing the competition for resources with larger char, which the trout cannot eat. The ecosystem has maintained balanced predator-prey populations for upwards of 15 years, with the trout feeding on small char and limiting the average size of the population (Suding and Hobbs 2009).

These two studies have additional ecological lessons that could inform the Cape seal cull. First, the moose study demonstrated that a decline in the population of one form of prey, in this case, caribou, can in fact reduce the abundance of a predator, in this case, wolf. However, it also tells us that another prey of the same predator, in this case, moose, may fill the open niche space and support the predator population. In addition to the gray seal, there are other species of seals on Cape Cod, most notably the harbor seal, upon which white sharks also prey. We know from the Link Food Web (Figure 3) that both species occupy similar feeding niches. Both seal species have been in recovery since 1972. If the gray seal is responsible for the white shark sighting increase, will culling the gray seals reduce the sightings or will the harbor seal population grow into the niche left by the gray seals?

In the trout/char study, culling of the larger individuals within the prey population led to stable recovery of the size-specific predator. This raises a question as to whether specific size targeting of the gray seal cull might have implications for the white shark population in the area. If, for example, older, larger seals were to be targeted and pups avoided, the average size of individuals in the population will decrease. As discussed above, young white sharks are size-dependent feeders, with smaller sharks utilizing smaller prey. Would a population in which individuals are smaller on average recruit younger, smaller white sharks to the area?

Culling to balance resource competition. There are numerous examples of marine mammal culls that are conducted because of perceived resource competition with humans and even other marine mammals. In most cases, culls were conducted without measurement of the outcome of interest and thus offer no clear guidance regarding the Cape Cod gray seals. Gray seals have been culled by 25 percent in Norway through an annual bounty hunt with the goal of protecting coastal fisheries. While the seal population appears to have stabilized, the response of any fish stocks has not been measured (Nilssen and Haug 2007). Gray and Harbor seals have been culled in Scotland ostensibly to protect salmon fisheries without any measurements of success (Thompson et al. 2007). In Japan, one of the most dramatic marine mammal culls happens each year in Taiji where 1500 to 2500 dolphins are herded into a cove and killed by Japanese fishermen who perceive the dolphins to be competing with them for fish stocks. No measure of fish population dynamics has been made to support this cull (Lavigne 2003). 
Morissette et al. (2012) developed a model to test whether culling marine mammals would have any effect on commercial fish stocks. The results of their testing suggest that, in fact, removal of marine mammals from the ecosystem would likely result in decreases in fishery yields. As described above, seals are generalist feeders that may regulate multiple fish species within the food web, including those that prey on the young of fiscally important species. In a review of predator removal ecosystem-based outcomes, Lennox et al. (2018) concluded that culling was an ineffective and costly management strategy for resolution of resource competition between humans and predators (Lennox et al. 2018).

In Washington State, seals and sea lions have been perceived to be competing with the endangered Southern Resident Killer Whales, Orcinus orca (Linneaus, 1758), for endangered chinook salmon, Oncorhynchus tshawytscha (Walbaum in Artedi, 1792, (Chasco et al. 2017). Since the building of hydroelectric dams on the Columbia River, salmon migration has been impeded (Dauble et al. 2003). Despite the placement of fish ladders at the dams, fish gather to wait at the bottom of the ladder becoming available for hungry seals and sea lions (Schilt 2007). A waiver was recently issued to the states of Oregon, Washington, and Idaho for lethal removal of "individually identifiable sea lions or seals that are having a "significant negative impact" on salmon and steelhead listed under the Endangered Species Act"25. The waiver allows the removal of up to 92 individuals per year that are observed consuming salmon and fail to be deterred by other methods. Of note, the California sea lion population on the West Coast is estimated to be in excess of $300,000^{26}$. These targeted culls of individual sea lions observed to be preying on salmon at the base of the Bonneville Dam have had little effect on depredation rates (Tidwell et al. 2017).

There is little to learn from marine mammal culls like these that are conducted to protect fisheries regarding the Cape gray seals because there are no evaluable outcome measurements. However, the ecological outcomes of the two studies on culling to protect threatened species presented above should be kept in mind when considering culling prey to control predator abundance. The moose study suggests that culling a prey population in certain cases can reduce the population of a predator; however, the trout study demonstrates the opposite outcome.

\footnotetext{
${ }^{25}$ Milstein, M. 2016 (May). NOAA Fisheries authorizes states to remove sea lions that threaten salmon.https://www.westcoast.fisheries.noaa.gov/newsroom/2016/05_noaa fisheries_authorizes states to remove sea lions that threaten salmon.html

${ }_{26}$ Milstein, M. 2016 (May). NOAA Fisheries authorizes states to remove sea lions that threaten salmon.https://www.westcoast.fisheries.noaa.gov/newsroom/2016/05 noaa fisheries authorizes states to remove sea lions that threaten salmon.html
} 


\section{Selective Culling}

Culling by age or gender. Selective culling is the practice of removing individuals with habits or traits from the population. The most well-known selective culling practice is the killing of seal pups in both Canada and Namibia. In the past, the hunting of seal pups occurred because of the commercial value of their coats which is greater than that of the adults. Despite the shrinking market for seal skins and products worldwide due to conservation and animal welfare concerns, the culling of pups continues to be a method of reducing the overall population to reduce perceived competition with fisheries (Lavigne 2003). In some years, Namibia has allowed the killing of 80,000 fur seal, Arctocephalus pusilus (Schreber, 1775), pups from a pupping of 135,000, effectively a 60 percent annual cull, to protect the profitable hake, Merluccius poli (Cadenat, 1950), fishing industry (MMFR 2004, de Klerk 2013). Canadian fishermen regard seals as depleting stocks of cod, Gadus morhua (Linnaeus, 1758), and capelin, Mallotus villosus (Muller, 1776), the cod's main dietary staple, thus the seal pup hunt continues despite the absence of markets for their products $^{27}$. However, no studies have been done in either location that demonstrate an association of culling by hunting of seals with recovery in the population of any stock fish (Bowen and Lidgard 2012).

Culling to remove problem individuals. In a situation where individual "rogue" animals are causing the identified problem, their specific removal may eliminate that problem. There are instances where selective management has produced sudden drops in impact, however, benefits can be short-lived as problem animals are replaced by others (Swan et al. 2017). Therefore, these strategies must be carefully evaluated and once implemented become ongoing to be effective.

In South Africa, culling 61 Cape fur seals that were observed to be preying on threatened Cape Gannet, Morus capensis (Lichtenstein, 1823), fledglings resulted in an immediate short-term reduction in the Gannet mortality; however, predation on gannet fledglings resumed within weeks of cessation of the cull (Makhado et al. 2009). Additionally, it was noted during the cull that seals learned to avoid boats and humans effectively evading a perceived predator. Selective culling has been successful in isolated cases in birds where individuals were removed who could be demonstrated to be responsible for the bulk of the impact on the prey species but the work involved in identifying those individuals makes the strategy impracticable on a large scale (Sanz-Aguilar et al. 2009, Hall and Kress 2008).

Selective culling has little to offer regarding the Cape gray seal cull; however, it has been proposed that if white sharks could be identified that regularly hunt close to beaches, there might be a reasonable argument that removing those individual sharks might forward the goal of reducing human-

27 Fink, S. 2017 (March 27). Fisheries unions request that seal hunt start early. IFAW.org https://www.ifaw.org/canada/news/fisheries-unions-request-seal-hunt-start-early 
shark encounters (Clua and Linnell 2018). However, the response of the South African seals to the culling process might be an indication of the difficulties involved in culling animals with a facility for behavioral learning.

\section{Culling for removal of invasive species}

Jones et al. reviewed 30 studies on eradication of invasive species on islands and found that 236 different native island species have benefitted from eradication on 181 islands making this type of culling one of the most successful conservation interventions (Jones et al. 2016). One such example is the extirpation of feral pigs from the Channel Islands in California. Pigs were introduced there over 150 years ago. They reproduced rapidly and become feral. Shortly thereafter, Golden Eagles, Aquila chrysaetos (Linnaeus, 1758), which were previously rare on the islands, found the pigs and began feeding on them. Unfortunately, they also found the native Channel Island foxes, Urocyon littoralis (Baird, 1858), and ate them to the brink of extinction. To save the foxes, $100 \%$ of feral pigs on the islands were culled. To protect the remaining foxes from additional predation, Golden Eagles were caught and relocated. After 15 years, the fox population has recovered, and the eagles have not returned (Coonan 2010).

On Macquarie Island in Australia, a similar event occurred. Macquarie was a stopping place for early sealers who incidentally introduced mice and rats to the island. They left their cats to manage these pests. Rabbits were later introduced to the island as a food source for the sealers. By the mid-20th century, the island was overrun by feral cats that were extirpated in a culling program. With the cats gone, the rabbit population exploded, decimating food resources and disrupting the landscape with burrows. Subsequent extirpation of the rabbits took place and the island is now recovering its native populations (Zavaleta et al. 2001).

In the case of invasive species culling, there may be a lesson for the Cape gray seal case. In both cases, the initial culling event had to be followed by the removal of a second species to achieve ecosystem stability. As previously discussed, the harbor seal population could expand throughout the shared range and continue to provide prey for white sharks thus necessitating an additional cull.

\section{Discussion and Conclusions}

This study was undertaken to investigate whether the scientific literature as it currently stands could inform a policy decision to consider a cull of gray seals on Cape Cod, the goal of which would be to minimize human-white shark encounters. It is important to acknowledge that while in the best of worlds, scientific expertise should be an essential component of public policy decisionmaking, economic, legal, and socio-political concerns must also be considered. 
An economic assessment is beyond the scope of this study. Legal considerations would involve obtaining a waiver through NOAA prior to any culling activity.

Socio-political considerations may be informed by a recent study by Jackman et al. (2018) who surveyed stakeholder views of potential lethal removal of seals from Nantucket Island. Of note, this study was performed prior to the human-shark encounters of September-October of 2018. In this study, stakeholders were classified as "Public", "On-site Anglers (recreational)", and "Tourists" (Jackman et al. 2018). Opposition to lethal management was reported for all three groups, with that of tourists being highest, suggesting that a cull could adversely impact a primary income source for local residents.

It is not unreasonable that those whose livelihood depends on the Cape's shores should look to removing a perceived threat to their safety, particularly in the wake of a tragedy. The assumption among some of the local residents as expressed at public meetings is that culling the seals should effectively rewind the ecosystem to its pre-1972 state with a minimal residual seal colony and no sharks. However, major ecological changes do not easily reverse. It is possible that even if the local gray seal population could be effectively reduced, we would see unanticipated effects of the cull as shown in Table 1.

At this time, the scientific literature does not support a gray seal cull. Given the current rate of population growth and influx of individuals from the north, there is no real likelihood of reduction of the local gray seal population on Cape Cod through lethal removal alone. Consideration should be given to the possibility of investigating oral spaying. A spaying program could be more humane by all stakeholders and be better received at the state and federal levels. Contraceptive programs for White-tailed deer population control have gained wide socio-political acceptance including approval by the Humane Society of the United States ${ }^{28}$.

From the literature review on northwest Atlantic gray seal biology and ecology, population counts, and prior culling studies, a cull of the gray seals on Cape Cod would not significantly reduce the risk of white shark-human encounters. Options for beach protection like those utilized in other parts of the world where white sharks are endemic should be investigated as the optimal short-term fix to protect swimmers and preserve the recreational income from Cape Cod's beaches. In addition, aerial and water surveillance for sharks near beaches could continue to inform beach closures and swimming should be discouraged in the presence of seals.

Within the near future, ongoing studies of the local white shark population and behavior as well as those of the gray seal population and behavior will hopefully provide guidance on how to modify our use of the near-shore waters to avoid human-shark encounters. These studies could identify spatial and

\footnotetext{
${ }^{28}$ Block, K. 2017 (July 11). EPA gives thumbs up to manage deer populations humanely. A Humane World. $\quad$ https://blog.humanesociety.org/2017/07/epa-gives-thumbs-vaccine-manage-deerpopulations-humanely.html
} 
temporal patterns of shark and/or seal activity that would facilitate a safe enjoyment of an extraordinary ecosystem.

Table 1: Possible outcomes of gray seal culling based on literature review

\begin{tabular}{|l|l|}
\hline \multicolumn{1}{|c|}{$\begin{array}{c}\text { Ecological Outcome of } \\
\text { Culling }\end{array}$} & \multicolumn{1}{|c|}{ Potential Unanticipated Consequences } \\
\hline $\begin{array}{l}\text { Social perturbation leading } \\
\text { to migration out of culling } \\
\text { area }\end{array}$ & $\begin{array}{l}\text { Seals are currently hauling out on the south side of the } \\
\text { Cape, leaving north side beaches free from both human- } \\
\text { seal and human-shark. If through culling they flee the } \\
\text { south side for the north side, no safe beaches could be } \\
\text { guaranteed which would be an economic disaster. }\end{array}$ \\
\hline $\begin{array}{l}\text { Release of one prey species } \\
\text { with the culling of another }\end{array}$ & $\begin{array}{l}\text { The culling of gray seals could lead to population } \\
\text { growth in harbor seals to fill vacant niche space }\end{array}$ \\
\hline $\begin{array}{l}\text { Decrease white shark } \\
\text { predator population with } \\
\text { gray seal prey culling }\end{array}$ & $\begin{array}{l}\text { This would be the desired effect; however, it would } \\
\text { likely take a massive ongoing cull given the movements } \\
\text { of the gray seal population into the area from northern } \\
\text { regions }\end{array}$ \\
\hline $\begin{array}{l}\text { Culling organisms of a } \\
\text { certain size can increase } \\
\text { predator population }\end{array}$ & $\begin{array}{l}\text { Culling older, larger seals, could reduce the average } \\
\text { size of seals in the population which could potentially } \\
\text { attract smaller, younger white sharks to the area }\end{array}$ \\
\hline $\begin{array}{l}\text { Ecosystem stability may } \\
\text { require culling more than } \\
\text { one species }\end{array}$ & $\begin{array}{l}\text { If the harbor seal population expands and supports the } \\
\text { white shark predators, an additional harbor seal cull } \\
\text { could be required }\end{array}$ \\
\hline $\begin{array}{l}\text { Use of an oral spaying } \\
\text { agent can be as effective as } \\
\text { culling for some desired } \\
\text { outcomes }\end{array}$ & $\begin{array}{l}\text { This would be a desired effect. Culling the seal } \\
\text { population without blood would be a preferable } \\
\text { sociopolitical outcome. }\end{array}$ \\
\hline
\end{tabular}

\section{Acknowledgments}

The assistance of A. Schiffman in proof-reading earlier versions of this manuscript is greatly appreciated. Eight scientists, mostly experts on sharks and/or seals, reviewed this paper and offered valuable suggestions.

\section{Literature Cited}

Albert, C., G. M. Luque, and F. Courchamp. 2018. The twenty most charismatic species. PloS One 13(7):e0199149. https://doi.org/10.1371/journal.pone.0199149

Ampela, K., 2009. The Diet and Foraging Ecology of Gray Seals (Halichoerus grypus) in United States Waters. Graduate Faculty in Biology. City University of New York. New York, NY, USA. $\quad 352 \quad$ pp. $\quad$ https://www.nefsc.noaa.gov/program review/2015review/BACKGROUND/B2C6Waring\%20diet\%20and\%20foraging.pdf

Andrews, J. C. and P. R. Mott. 1967. Gray seals at Nantucket, Massachusetts. Journal of Mammalogy 48(4):657-658. https://doi.org/10.2307/1377597 
Atkinson, S. 1997. Reproductive biology of seals. Reviews of Reproduction 2(3):175-194. https://doi.org/10.1530/ror.0.0020175

Aznar, I., K. Frankena, S. J. More, J. O'Keeffe, G. McGrath, and M. C. M. de Jong. 2018. Quantification of Mycobacterium bovis transmission in a badger vaccine field trial. Preventive Veterinary Medicine 149:29-37. https://doi.org/10.1016/j.prevetmed.2017.10.010

Beeton, N. and H. McCallum. 2011. Models predict that culling is not a feasible strategy to prevent extinction of Tasmanian devils from facial tumour disease: Modelling removal of diseased devils. The Journal of Applied Ecology 48(6):1315-1323. https://doi.org/10.1111/j.13652664.2011.02060.x

Bielby, J., F. Vial, R. Woodroffe, and C. A. Donnelly 2016. Localised badger culling increases risk of herd breakdown on nearby, not focal, land. PloS One 11(10): 0164618. https://doi.org/10.1371/journal.pone.0164618

Bleicher, S. S. 2017. The landscape of fear conceptual framework: definition and review of current applications and misuses. PeerJ 5:e3772. https://doi.org/10.7717/peerj.3772

Bowen, W. D. and D. Lidgard. 2012. Marine mammal culling programs: Review of effects on predator and prey populations. Mammal Review 43(3):207-220. https://doi.org/10.1111/j.13652907.2012.00217.x

Bowen, W. D., J. McMillan, and R. Mohn. 2003. Sustained exponential population growth of grey seals at Sable Island, Nova Scotia. ICES Journal of Marine Science: Journal du Conseil 60(6):1265-1274. https://doi.org/10.1016/S1054-3139(03)00147-4

Bowen, W. D., J. I. McMillan, and W. Blanchard. 2007. Reduced population growth of gray seals at Sable Island: Evidence from pup production and age of primiparity. Marine Mammal Science 23(1), pp.48-64. https://doi.org/10.1111/j.1748-7692.2006.00085.x

Brown, R. G., W. D. Bowen, J. D. Eddington, W. C. Kimmins, M. Mezei, J. L. Parsons, and B. Pohajdak. 1997. Evidence for a long-lasting single administration contraceptive vaccine in wild grey seals. Journal of Reproductive Immunology 35(1):43-51. https://doi.org/10.1016/S0165$\underline{0378(97) 00047-8}$

Bruce, B. D. 2008 The Biology and Ecology of the White Shark, Carcharodon carcharias. pp. 6981. In, Camhi, M. D., E. K. Pikitch, and E. A. Babcock (Editors). Sharks of the Open Ocean: Biology, Fisheries and Conservation. Blackwell Publishing Ltd. Oxford, England, UK. 502 pp. https://onlinelibrary.wiley.com/doi/book/10.1002/9781444302516

Castro, J. I. 2012. A summary of observations on the maximum size attained by the white. Chapter 7. pp. 85-90. Global Perspectives on the Biology and Life History of the White Shark. In, Domeier, M. L. (Editor). Global Perspectives on the Biology and Life History of the White Shark. CRC Press. Taylor and Francis Group. Boca Raton, Florida, USA. 543 pp.

Chasco, B. E., I. C. Kaplan, A. C. Thomas, A. Acevedo-Gutiérrez, D. P. Noren, M. J. Ford, M. Bradley Hanson, J. J. Scordino, S. J. Jeffries, K. N. Marshall, A. O. Shelton, C. Matkin, B. J. Burke, and E. J. Ward. 2017. Competing tradeoffs between increasing marine mammal predation and fisheries harvest of chinook salmon. Scientific Reports 7(1):15439. https://doi.org/10.1038/s41598-017-14984-8

Clua, E. E. G. and J. D. C. Linnell. 2018. Individual shark profiling: An innovative and environmentally responsible approach for selectively managing human fatalities. Conservation Letters 14:e12612. https://doi.org/10.1111/conl.12612

Coonan, T. J., C. A. Schwemm, and D. K. Garcelon. 2010. Decline and Recovery of the Island Fox: A Case Study for Population Recovery. Cambridge University Press. Cambridge, U.K. 229 pp. https://doi.org/10.1017/CBO9780511781612

Corkeron, P. J. 2009. Marine mammals' influence on ecosystem processes affecting fisheries in the Barents Sea is trivial. Biology Letters 5(2):204-206. https://doi.org/10.1098/rsbl.2008.0628

Curtis, T. H., G. Metzger, C. Fischer, B. McBride, M. McCallister, L. J. Winn, J. Quinlan, and M. J. Ajemian. 2018. First insights into the movements of young-of-the-year white sharks (Carcharodon carcharias) in the western North Atlantic Ocean. Scientific Reports 8(1):10794. https://doi.org/10.1038/s41598-018-29180-5

Dauble, D. D., T. P. Hanrahan, D. R. Geist, and M. J. Parsley. 2003. Impacts of the Columbia River hydroelectric system on main-stem habitats of fall chinook salmon. North American Journal of 
Fisheries Managementh 23(3):641-659. https://doi.org/10.1577/M02-013

Davis, C. S., I. Stirling, C. Strobeck, and D. W. Coltman. 2008. Population structure of ice-breeding seals. Molecular Ecology 17(13):3078-3094. https://doi.org/10.1111/j.1365294X.2008.03819.x

DFO. 2017. Stock assessment of Canadian northwest Atlantic grey seals (Halichoerus grypus). DFO Can. Sci. Advis. Sec. Sci. Advis. Rep. 2017/045.https://www.dfo-mpo.gc.ca/csassccs/Publications/SAR-AS/2017/2017_045-eng.html.

Dunne, J. A., R. J. Williams, and N. D. Martinez. 2004. Network structure and robustness of marine food webs. Marine Ecology Progress Series 273:291-302. https://doi.org/10.3354/meps273291

Eklund, A., J. V. López-Bao, M. Tourani, G. Chapron, and J. Frank. 2017. Limited evidence on the effectiveness of interventions to reduce livestock predation by large carnivores. Scientific Reports 7(1):2097. https://doi.org/10.1038/s41598-017-02323-w

Estrada, J. A., A. N. Rice, L. J. Natanson, G. B. Skomal. 2006. Use of isotopic analysis of vertebrae in reconstructing ontogenetic feeding ecology in white sharks. Ecology 87(4):829-834. https://doi.org/10.1890/0012-9658(2006)87[829:UOIAOV]2.0.CO;2

Ferretti, F., S. Jorgensen, T. K. Chapple, G. De Leo, and F. Micheli. 2015. Reconciling predator conservation with public safety. Frontiers in Ecology and the Environment 13(8):412-417. https://doi.org/10.1890/150109

Freuling, C. M., K. Hampson, T. Selhorst, R. Schröder, F. X. Meslin, T. C. Mettenleiter, and T. Müller. 2013. The elimination of fox rabies from Europe: determinants of success and lessons for the future. Philosophical Transactions of the Royal Society of London. Series B, Biological Sciences 368(1623):20120142, 13 pp. https://doi.org/10.1098/rstb.2012.0142

Gilbert, J. R., G. T. Waring, K. M. Wynne, and N. Guldager. 2005. Changes in abundance of harbor seals in Maine, 1981-2001. Marine Mammal Science 21(3):519-535. https://doi.org/10.1111/j.1748-7692.2005.tb01246.x

Gortazar, C., I. Diez-Delgado, J. A. Barasona, J. Vicente, J. De La Fuente, and M. Boadella. 2014. The wild side of disease control at the wildlife-livestock-human interface: a review. Frontiers in Veterinary Science 1:27- . https://doi.org/10.3389/fvets.2014.00027

Gudger, E. W. 1950. A boy attacked by a shark, July 25, 1936 in Buzzard's Bay, Massachusetts with notes on attacks by another shark along the New Jersey coast in 1916. The American Midland Naturalist 44(3):714-719. https://doi.org/10.2307/2421830

Hall, A. and D. Thompson. 2009. Gray Seal: Halichoerus grypus. In, Perrin, W. F., B. Würsig, and J. G. M. Thewissen (Editors). Encyclopedia of Marine Mammals (Second Edition). pp. 500503. London Academic Press. London, England, UK. 1,316 pp. https://doi.org/10.1016/B9780-12-373553-9.00118-8

Hall, C. S. and S. W. Kress. 2008. Diet of nestling black-crowned night-herons in a mixed species colony: implications for tern conservation. The Wilson Journal of Ornithology 120(3):637640. https://doi.org/10.1676/07-035.1

Hamady, L. L., L. J. Natanson, G. B. Skomal, and S. R. Thorrold. 2014. Vertebral bomb radiocarbon suggests extreme longevity in white sharks. PloS One 9(1):e84006. https://doi.org/10.1371/journal.pone.0084006

Hammill, M. O., C. E. den Heyer, W. D. Bowen, and S. L. C. Lang. 2017. Grey seal population trends in Canadian waters, 1960-2016 and harvest advice. Fisheries and Oceans Canada. Canadian Science Advisory Secretariat. Ottawa, Ontario, Canada. Doc. 2017/052. v + 30 pp. https://www.researchgate.net/profile/William_Bowen3/publication/323477033_Canadian_Scie nce Advisory Secretariat CSAS Grey Seal Population Trends in Canadian Waters 19602016 and Harvest Advice/links/5a97e239a6fdccecff0bb821/Canadian-Science-Advisory-

Secretariat-CSAS-Grey-Seal-Population-Trends-in-Canadian-Waters-1960-2016-and-HarvestAdvice.pdf

Hayes, S. A., E. Josephson, K. Maze-Foley, P. E. Rosel, B. Byrd, S. Chavez-Rosales, T. V. N. Cole, L. Engleby, L. P. Garrison, J. Hatch, A. Henry, S. C. Horstman, J. Litz, Marjorie C. Lyssikatos, K. D. Mullin, C. Orphanides, R. M. Pace, D. L. Palka, M. Soldevilla, and F. W. Wenzel. 2018. TM 245 US Atlantic and Gulf of Mexico Marine Mammal Stock Assessments-2017. NOAA Tech Memo NMFS NE, 245, p. 371. https://www.nefsc.noaa.gov/publications/tm/tm245/\# 
Heupel, M. R., J. K. Carlson, and C. A. Simpfendorfer. 2007. Shark nursery areas: concepts, definition, characterization and assumptions. Marine Ecology Progress Series 337:287-297. https://doi.org/10.3354/meps337287

Houston, A. I., P. A. Stephens, I. L. Boyd, K. C. Harding, and J. M. McNamara. 2007. Capital or income breeding? A theoretical model of female reproductive strategies. Behavioral Ecology: Official Journal of the International Society for Behavioral Ecology 18(1):241-250. https://doi.org/10.1093/beheco/arl080

Hussey, N. E., H. M. McCann, G. Cliff, S. F. J. Dudley, S. P. Wintner, and A. T. Fisk. 2012. Sizebased analysis of diet and trophic position of the white shark (Carcharodon carcharias) in South African waters. Chapter 3. pp. 27-49. In, Domeier, M. L. (Editor). Global Perspectives on the Biology and Life History of the White Shark. CRC Press. Boca Raton, Florida, USA. 543 pp.

Jackman, J., L. Bettencourt, J. Vaske, M. Sweeney, K. Bloom, A. Rutberg, and B. Brook. 2018. Conflict and consensus in stakeholder views of seal management on Nantucket Island, MA, USA. Marine Policy 95:166-173. https://doi.org/10.1016/j.marpol.2018.03.006

Johnston, D. W., J. Frungillo, A. Smith, K. Moore, B. Sharp, J. Schuh, and A. J. Read. 2015. Trends in stranding and by-catch rates of gray and harbor seals along the northeastern coast of the United States: Evidence of divergence in the abundance of two sympatric phocid species? PloS One 10(7):e0131660. https://doi.org/10.1371/journal.pone.0131660

Jones, H. P., N. D. Holmes, S. H. M. Butchart, B. R. Tershy, P. J. Kappes, I. Corkery, A. AguirreMuñoz, D. P. Armstrong, E. Bonnaud, A. A. Burbidge, K. Campbell, F. Courchamp, P. E. Cowan, R. J. Cuthbert, S. Ebbert, P. Genovesi, G. R. Howald, B. S. Keitt, S. W. Kress, C. M. Miskelly, S. Oppel, S. Poncet, M. J. Rauzon, G. Rocamora, J. C. Russell, A. SamaniegoHerrera, P. J. Seddon, D. R. Spatz, D. R. Towns, and D. A. Croll. 2016. Invasive mammal eradication on islands results in substantial conservation gains. Proceedings of the National Academy of Sciences of the United States of America 113(15):4033-4038. https://doi.org/10.1073/pnas.1521179113

Judge, J., G. J. Wilson, R. Macarthur, R. A. McDonald, and R. J. Delahay. 2017. Abundance of badgers (Meles meles) in England and Wales. Scientific Reports 7(1):276. https://doi.org/10.1038/s41598-017-00378-3

Katona, S.K., V. Rough, and D. T. Richardson. 1993. A Field Guide to Whales. Porpoises and Seals from Cape Cod to New Foundland. Smithsonian Institution Press. Washington, District of Columbia, USA. 316 pp.

Klemetsen, A., P.-A. Amundsen, P. E. Grotnes, R. Knudsen, R. Kristoffersen, and M.-A. Svenning. 2002. Takvatn through 20 years: long-term effects of an experimental mass removal of Arctic charr, Salvelinus alpinus, from a subarctic lake. pp. 39-47. In, Magnan, P., C. Audet, H. Glémet, M. Legault, M. A. Rodriguez, and E. B. Taylor (Editors). Ecology, Behaviour and Conservation of the charrs, genus Salvelinus. Selected papers from the 4th International Charr Symposium, 25 June-1 July 2000, Québec, Canada. Environmental Biology of Fishes 64(1/3):1-351. https://doi.org/10.1007/978-94-017-1352-8_3

de Klerk, S., 2013. Seal harvesting in Namibia: A critical Analysis. A dissertation submitted in partial fulfillment of the requirements for the award of the Bachelor of Laws (LLB) degree. The University of Namibia. $101 \mathrm{pp}$. https://www.harpseals.org/about the hunt/s.de klerknamibia seal harvesting analysis-dissertation 2013.pdf

Kugeler, K. J., R. A. Jordan T. L. Schulze K. S. Griffith P. S. Mead. 2016. Will culling whitetailed deer prevent Lyme disease? Zoonoses and Public Health, 63(5):337-345. https://doi.org/10.1111/zph.12245

Lachish, S., H. McCallum, D. Mann, C. E. Pukk, and M. E. Jones. 2010. Evaluation of selective culling of infected individuals to control Tasmanian devil facial tumor disease. Conservation Biology: The Journal of the Society for Conservation Biology 24(3):841-851. doi: 10.1111/j.1523-1739.2009.01429.x.

Lavigne, D. M. 2003. Marine mammals and fisheries: the role of science in the culling debate. pp. 31-47. In, Gales, N., M. Hindell, R. Kirkwood (Editors). Marine Mammals: Fisheries, Tourism and Management Issues. CSIRO Publishing. Collingwood, VIC, Australia. 446 pp. 
Lelli, B., D. E. Harris, and A.-M. Aboueissa. 2009. Seal bounties in Maine and Massachusetts, 1888 to 1962. Northeastern Natualist 16(2):239-254. https://doi.org/10.1656/045.016.0206

Lennox, R. J., A. J. Gallagher, E. G. Ritchie, and S. J. Cooke. 2018. Evaluating the efficacy of predator removal in a conflict-prone world. Biological Conservation 224: 277-289. https://doi.org/10.1016/j.biocon.2018.05.003

Link, J., 2002. Does food web theory work for marine ecosystems? Marine ecology progress series, 230, pp.1-9. https://doi.org/10.3354/meps230001

Lonergan, M., D. Thompson, L. Thomas, and C. Duck. 2011. An approximate Bayesian method applied to estimating the trajectories of four British grey seal (Halichoerus grypus) populations from pup counts. Journal of Marine Biology 2011, Article ID 597424, 7 pages. https://doi.org/10.1155/2011/597424

Madden, F. M. 2008. The growing conflict between humans and wildlife: law and policy as contributing and mitigating factors. Journal of International Wildife Law \& Policy 11(23):189-206. https://doi.org/10.1080/13880290802470281

Makhado, A. B., M. A. Meÿer, and R. J. M. Crawford. 2009. The efficacy of culling seals seen preying on seabirds as a means of reducing seabird mortality. African Journal of Ecology 47(3):335-340._https://doi.org/10.1111/j.1365-2028.2008.00966.x

Manjerovic, M. B., M. L. Green, N. Mateus-Pinilla, J. Novakofski. 2014. The importance of localized culling in stabilizing chronic wasting disease prevalence in white-tailed deer populations. Preventive Veterinary Medicine 113(1):139-145. https://doi.org/10.1016/j.prevetmed.2013.09.011

Manning, F. and E. Hubley (Chair and Deputy Chair, respectively), M. Harb, C. Hervieux-Payette, S. Lovelace Nicholas, M. L. MacDonald, T. Johnson McInnis, J. Munson, D. H. Oliver, R.-M. Poirier, N. Greene Raine, B. E. Unger. 2012. The sustainable management of grey seal populations: A path toward the recovery of cod and other groundfish stocks. In, Report of the Standing Senate Committee on Fisheries and Oceans. https://sencanada.ca/content/sen/Committee/411/pofo/rep/rep07oct12-e.pdf

Mayer, L. P. and C. A. Dyer. 2018. Reducing the reproductive capacity of mammals. US Patent. https://patentimages.storage.googleapis.com/c8/5b/59/5ff5beb82b4acd/US20180207181A1.pdf

McDonald, R. A. 2014. Badgers and bovine tuberculosis. Current Biology: CB 24(4):R141-3. https://doi.org/10.1016/j.cub.2013.12.014

MMFR 2004. Republic of Namibia Fisheries and Marine Resources: Marine Resources Policy 2004 White

Paper. https://www.mfmr.gov.na/documents/120354/165201/Marine+Resources+Policy+2004.pdf/48 62b255-17c1-4d86-97fc-5dc339e21ac3

Morissette, L., V. Christensen, and D. Pauly. 2012. Marine mammal impacts in exploited ecosystems: would large scale culling benefit fisheries? PloS One 7(9):e43966. https://doi.org/10.1371/journal.pone.0043966

Moxley, J. H., A. Bogomolni, M. O. Hammill, K. M. T. Moore, M. J. Polito, L. Sette, W. B. Sharp, G. T. Waring, J. R. Gilbert, P. N. Halpin, and D. W. Johnston. 2017. Google haul out: Earth observation imagery and digital aerial surveys in coastal wildlife management and abundance estimation. Bioscience 67(8):760-768. https://doi.org/10.1093/biosci/bix059

Murray, M. J. 2008. Behavioral Interactions Between Harbor Seals (Phoca vitulina) and Gray Seals (Halichoerus grypus) on Cape Cod, Massachusetts. Northeastern University (Boston, Massachussetts, USA). Master's Thesis. Department of Biology. 56 pp. https://repository.library.northeastern.edu/files/neu:621

Nilssen, K.T. and T. Haug. 2007. Status of grey seals (Halichoerus grypus) in Norway. NAMMCO Scientific Publications 6(0):23-31. https://doi.org/10.7557/3.2719

Noren, S. R., S, J. Iverson, and D. J. Boness. 2005. Development of the blood and muscle oxygen stores in gray seals (Halichoerus grypus): implications for juvenile diving capacity and the necessity of a terrestrial postweaning fast. Physiological and Biochemical Zoology: PBZ 78(4):482-490. https://doi.org/10.1086/430228

Pace, R. M., W. Josephson, S. A. Wood, K. Murray, and G. Waring. 2019. Trends and Patterns of Seal Abundance at Haul-out Sites in a Gray Seal Recolonization Zone. NOAA Technical 
Memorandum NMFS-NE-251. https:/www.nefsc.noaa.gov/publications/tm/tm251/tm251.pdf

Payne, P. M. and L. A. Selzer. 1989. The distribution, abundance and selected prey of the harbor seal, Phoca vitulina concolor, in southern New England. Marine Mammal Science 5(2):173192. https://doi.org/10.1111/j.1748-7692.1989.tb00331.x

Persson, L., P.-A. Amundsen, A. M. De Roos, A. Klemetsen, R. Knudsen, and R. Primicerio. 2007. Culling prey promotes predator recovery - alternative states in a whole-lake experiment. Science 316(5832):1743-1746. https://doi.org/10.1126/science.1141412

Pomeroy, P. P., S. D. Twiss, and P. Redman. 2000. Philopatry, site fidelity and local kin associations within Grey Seal breeding colonies. Ethology: formerly Zeitschrift fur Tierpsychologie 106(10):899-919. https://doi.org/10.1046/j.1439-0310.2000.00610.x

Ripple, W. J., J. A. Estes, O. J. Schmitz, V. Constant, M. J. Kaylor, A. Lenz, J. L. Motley, K. E. Self, D. S. Taylor, and C. Wolf. 2016. What is a trophic cascade? Trends in Ecology \& Evolution 31(11):842-849. https://www.sciencedirect.com/science/article/pii/S0169534716301379

Rough, V. 1995. Gray Seals in Nantucket Sound, Massachusetts, Winter and Spring, 1994. Final Report to US Marine Mammal Commission. Contract T10155615. National Technical Information Service Publication PB95-191391. Marine Mammal Commission. Bethesda, Maryland, USA. 28 pp. https://babel.hathitrust.org/cgi/pt?id=uc1.31822020655338;view=1up;seq=34

Saint-Béat, B., D. Baird, H. Asmus, R. Asmus, C. Bacher, S. R. Pacella, G. A. Johnson, V. David, Alain F. Vézina, and N. Niquila. 2015. Trophic networks: How do theories link ecosystem structure and functioning to stability properties? A Review. Ecological Indicators 52:458-471. https://doi.org/10.1016/j.ecolind.2014.12.017

Sanz-Aguilar, A., A. Martínez-Abraín, G. Tavecchia, E. Mínguez, and D. Oro. 2009. Evidencebased culling of a facultative predator: Efficacy and efficiency components. Biological Conservation 142(2):424-431. https://doi.org/10.1016/j.biocon.2008.11.004

Schilt, C. R. 2007. Developing fish passage and protection at hydropower dams. Applied Animal Behaviour Science 104(3):295-325. https://doi.org/10.1016/j.applanim.2006.09.004

Seip, D. R. 1992. Factors limiting woodland caribou populations and their interrelationships with wolves and moose in southeastern British Columbia. Canadian Journal of Zoology 70(8):14941503. https://doi.org/10.1139/z92-206

Seip, D. R. 2008. Mountain caribou interactions with wolves and moose in central British Columbia. Alces: A Journal Devoted to the Biology and Management of Moose 44(0):1-5.

Serrouya, R., B. N. McLellan, S. Boutin, D. R. Seip, and S. E. Nielsen. 2011. Developing a population target for an overabundant ungulate for ecosystem restoration: Restoring a predatorprey system. The Journal of Applied Ecology 48(4):935-942. https://doi.org/10.1111/j.13652664.2011.01998.x

Serrouya, R., B. N. McLellan, H. van Oort, G. Mowat, S. Boutin. 2017. Experimental moose reduction lowers wolf density and stops decline of endangered caribou. PeerJ 5:e3736. https://doi.org/10.7717/peerj.3736

Shapiro, A. D., P. J. B. Slater, and V. M. Janik. 2004. Call usage learning in gray seals (Halichoerus grypus). Journal of Comparative Psychology 118(4):447-454. https://doi.org/10.1037/07357036.118.4.447

Singer, F. D. 2016. Ecology in Action. Cambridge University Press. Cambridge, England, UK. 704 pp

Skomal, G. B., C. D. Braun, J. H. Chisholm, and S. R. Thorrold. 2017. Movements of the white shark Carcharodon carcharias in the North Atlantic Ocean. Marine Ecology Progress Series 580:1-16. https://doi.org/10.3354/meps 12306

Skomal, G. B., J. Chisholm, and S. J. Correia. 2012. Implications of increasing pinniped populations on the diet and abundance of white sharks off the coast of Massachusetts. Chapter 27. pp. 405417. In, Domeier, M. L. (Editor). Global Perspectives on the Biology and Life History of the White Shark. CRC Press. Taylor and Francis Group. Boca Raton, Florida, USA. 543 pp. https://doi.org/10.1201/b11532-31

Stansbury, A. L., M. de Freitas, G.-M. Wu, and V. M. Janik. 2015. Can a gray seal (Halichoerus grypus) generalize call classes? Journal of Comparative Psychology 129(4):412-420. https://doi.org/10.1037/a0039756 
Suding, K. N. and R. J. Hobbs. 2009. Threshold models in restoration and conservation: a developing framework. Trends in Ecology \& Evolution 24(5):271-279. https://doi.org/10.1016/j.tree.2008.11.012

Swan, G. J. F., S. M. Redpath, S. Bearhop, R. A. McDonald. 2017. Ecology of problem individuals and the efficacy of selective wildlife management. Trends in Ecology \& Evolution 32(7):518530. https://doi.org/10.1016/j.tree.2017.03.011

Telford III, S. R. 2017. Deer reduction is a cornerstone of integrated deer tick management. Journal of Integrated Pest Management 8(1): https://doi.org/10.1093/jipm/pmx024

Thompson, P. M., B. Mackey, T. R. Barton, C. Duck, and J. R. A. Butler 2007. Assessing the potential impact of salmon fisheries management on the conservation status of harbour seals (Phoca vitulina) in north-east Scotland. Animal Conservation 10(1):48-56. https://doi.org/10.1111/j.1469-1795.2006.00066.x

Tidwell, K. S., B. van der Leeuw, L. N. Magill, B. A. Carrothers, and R. H. Wertheimer. 2017. Evaluation of Pinniped Predation on Adult Salmonids and Other Fish in the Bonneville Dam Tailrace, 2017. US Army Corps of Engineers. Bonneville Lock and Dam. Portland District Fisheries Field Unit. Cascade Locks, Oregon, USA. 47 pp. http://pweb.crohms.org/tmt/documents/FPOM/2010/Task\%20Groups/Task\%20Group\%20Pinn ipeds $/ 2017 \% 20$ USACE\%20pinniped\%20monitoring\%20report.pdf

van Eeden, L. M., C. R. Dickman, E. G. Ritchie, and T. M. Newsome. 2017. Shifting public values and what they mean for increasing democracy in wildlife management decisions. Biodiversity and Conservation 26(11):2759-2763. https://doi.org/10.1007/s10531-017-1378-9

Vilà, C. and J. A. Leonard. 2012. Canid phylogeny and origin of the domestic dog. pp. 1-11. In, Ostrander, E. A. and A. Ruvinsky (Editors). The Genetics of the Dog. Second Edition. CAB International (CABI). Wallingford, Oxfordshire, England, UK. $521 \mathrm{pp}$. https://doi.org/10.1079/9781845939403.0001

White, P. J., R. L. Wallen, C. Geremia, J. J. Treanor, and D. W. Blanton. 2011. Management of Yellowstone bison and brucellosis transmission risk - Implications for conservation and $\begin{array}{llll}\text { restoration. Biological Conservation } & \text { 144(5):1322-1334. }\end{array}$ https://doi.org/10.1016/j.biocon.2011.01.003

Wood LaFond, S. A. 2009. Dynamics of Recolonization: A Study of the Gray Seal in the Northeast US Ph. D. Dissertation. Department of Biology. University of Massachusetts. Boston, Massachusetts, USA. 83 pp.

Wood, S. A., T. R. Frasier, B. A. McLeod, J. R. Gilbert, B. N. White, W. D. Bowen, M. O. Hammill, G. T. Waring, S. Braulta. 2011. The genetics of recolonization: an analysis of the stock structure of grey seals (Halichoerus grypus) in the northwest Atlantic. Canadian Journal of Zoology 89(6):490-497. https://doi.org/10.1139/z11-012

Woods, G. M., S. Fox, A. S. Flies, C. D. Tovar, M. Jones, R. Hamede, D. Pemberton, A. B. Lyons, and S. S. Bettiol. 2018. Two decades of the impact of Tasmanian Devil Facial Tumor disease. Integrative and Comparative Biology 58(6):1043-1054. https://doi.org/10.1093/icb/icy118

Yodzis, P. 2001. Must top predators be culled for the sake of fisheries? Trends in Ecology \& Evolution 16(2):78-84. https://doi.org/10.1016/S0169-5347(00)02062-0

Waring, G. T., E. Josephson, K. Maze-Foley, P. F. Rosel, B. L. Byrd, et al. 2001-2015. Marine Mammal Stock Assessment Reports by Region | NOAA Fisheries. https://www.fisheries.noaa.gov/national/marine-mammal-protection/marine-mammal-stockassessment-reports-region

Zavaleta, E.S., R. J. Hobbs, and H. A. Mooney. 2001. Viewing invasive species removal in a wholeecosystem context. Trends in Ecology \& Evolution 16(8):454-459. https://doi.org/10.1016/S0169-5347(01)02194-2 


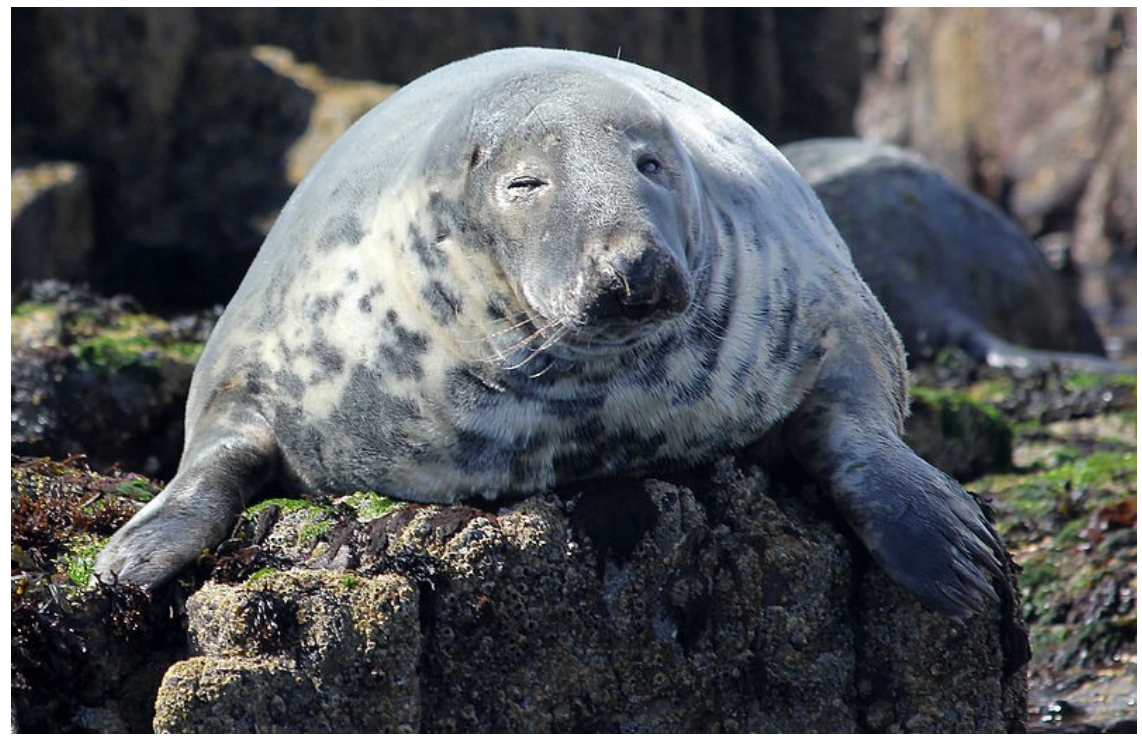

Gray Seal, Halichoerus grypus (Fabricius, 1791). Author: Dunpharlain. Source: Own work.

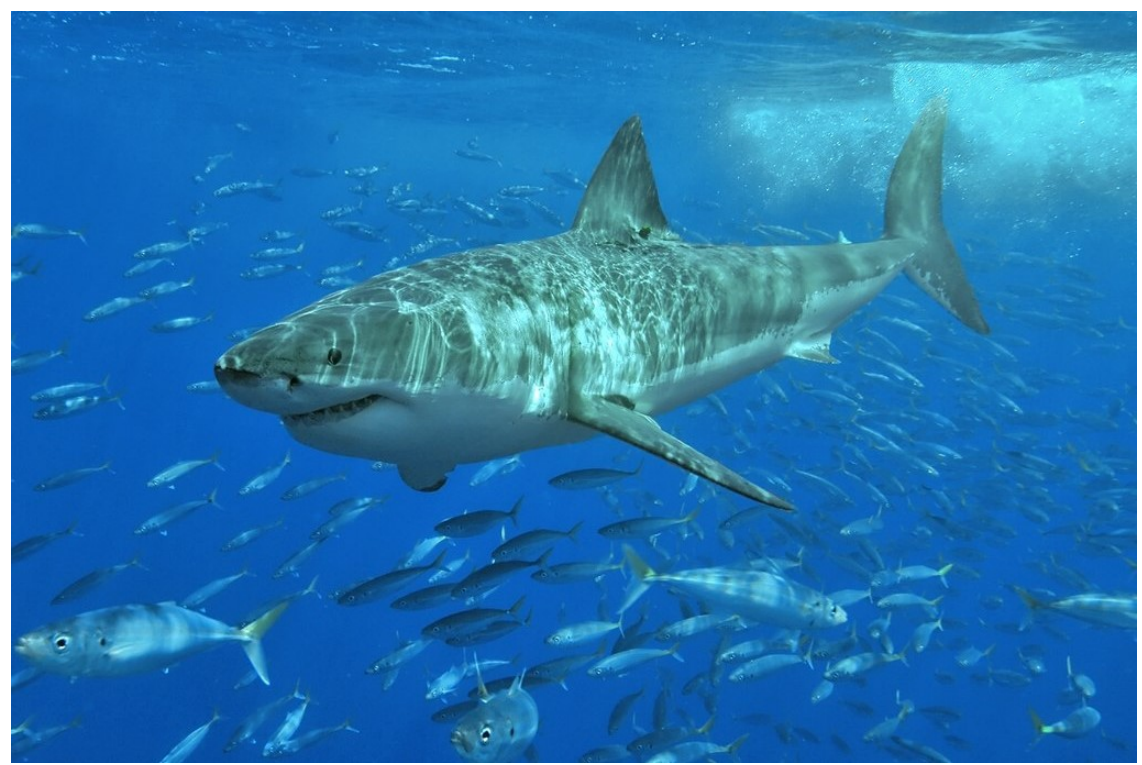

Great White shark, Carcharodon carcharias (Linnaeus, 1758). Author: English: Pterantula (Terry Goss) at en.wikipedia. Source: English: Derivative of w:Image:Whiteshark-TGoss5b.jpg. 